V. 13 N. 3

SET-DEZ 2017

ISSN 2317-6172

Recebido: 01.06.2016

Aprovado: 01.09.2017

Dol: http://dx.doi.org/10.1590/2317-6172201733

1 Faculdade Guanambi Guanambi - BA - Brasil

\section{Questões teóricas e metodológicas do direito na literatura: um percurso analítico-interpretativo a partir do conto Suje-se gordo!, de Machado de Assis}

THEORY AND METHODOLOGY OF LAW IN LITERATURE: AN ANALYTICAL JOURNEY BASED ON SUJE-SE GORDO!, A SHORT STORY BY BRAZILIAN WRITER MACHADO DE ASSIS

\section{Henriete Karam ${ }^{1}$}

\section{Resumo}

O significativo avanço dos estudos de Direito e Literatura no Brasil tem despertado o interesse dos juristas e incentivado os estudantes a desenvolverem pesquisas, sobretudo no campo do direito na literatura, sem, contudo, que thes sejam oferecidos o aparato conceitual, os pressupostos e os instrumentos a serem empregados na análise de textos literários. Considerando tal contexto, este artigo, além de apresentar alguns dados históricos e as diferentes correntes do Direito e Literatura, busca destacar a necessidade de que se enfrentem as questões teóricas e metodológicas implicadas em investigações de cunho interdisciplinar e utiliza o conto Suje-se gordo!, de Machado de Assis, no qual é problematizada a eficácia do tribunal do júri na concretização da justiça, para oferecer um modelo de percurso analítico-interpretativo que pode ser aplicado aos estudos dedicados ao direito na literatura.

\section{Palavras-chave}

Direito na literatura; questões teóricas e metodológicas; tribunal do júri; realização da justiça; Machado de Assis.

\section{Abstract}

The significant advance of Law and Literature studies in Brazil has attracted the interest of lawyers and encouraged students to develop research, especially in the field of law in literature. Many of these papers seem to lack, however, the conceptual apparatus, assumptions, and instruments necessary for the analysis of literary texts. Considering this context, this article, in addition to presenting some historical data and defining different currents of Law and Literature, emphasizes the need for specialized theoretical and methodological issues involved in such interdisciplinary investigations, and uses the short story Suje-se gordo!, by Brazilian writer Machado de Assis, which brings to question the effectiveness of the court regarding justice. The intention is to provide an analytical model that could be applied in different studies of law in literature.

\section{Keywords}

Law in literature; theoretical and methodological issues; law court; justice; Machado de Assis. 


\section{INTRODUÇÃO}

Ao longo da última década, a comunidade acadêmica jurídica do Brasil tem acompanhado o progressivo desenvolvimento do campo de estudos denominado Direito e Literatura, fenômeno análogo aos que ocorreram nos Estados Unidos e na Europa, sobretudo a partir da segunda metade do século XX.

No entanto, em que pese a quantidade de livros e de artigos publicados, o crescente número de dissertações e de teses, bem como a existência de periódico científico interdisciplinar dedicado exclusivamente à interlocução entre o direito e a literatura, ${ }^{1}$ a produção e a divulgação de tais estudos ainda se encontram circunscritas ao âmbito jurídico, pois são raros os especialistas da área de Letras que se aventuram nesse campo de estudo.

Em geral, limitada a pesquisadores da área do direito, não é de estranhar que parte da produção bibliográfica brasileira - especialmente quando a autoria é de estudantes de graduação e de pós-graduação - prescinda da fundamentação teórica e metodológica exigida na análise de textos literários, muito embora se concentre na corrente do direito na literatura. Disso resultam o enfraquecimento da natureza interdisciplinar dos estudos em Direito e Literatura e o risco de a literatura assumir papel meramente instrumental ou, até mesmo, ornamental.

Considerando tal contexto, este artigo é particularmente destinado aos pesquisadores iniciantes e, além de fornecer alguns dados históricos e breves informações sobre as principais correntes de investigação dos estudos em Direito e Literatura, tem como objetivo principal oferecer um modelo de percurso analítico-interpretativo que pode ser aplicado em estudos dedicados ao direito na literatura, sendo, para isso, explicitados os procedimentos adotados para o exame de questões jurídicas no conto Suje-se gordo!, de Machado de Assis.

\section{OS ESTUDOS SOBRE DIREITO E LITERATURA}

Com o declínio do positivismo jurídico e os desafios impostos pela instituição do Estado democrático de direito, em especial no que se refere à defesa dos direitos fundamentais, o movimento Direito e Literatura inaugura um peculiar e promissor campo interdisciplinar que oferece novas possibilidades de compreensão tanto da natureza humana e dos conflitos sociais quanto dos impasses e desafios que o direito enfrenta na contemporaneidade.

Contrapondo-se ao tradicional viés dogmático, cientificista e convencionalista do Direito, bem como ao seu caráter normativo e repressor, ${ }^{2}$ a literatura - que se caracteriza pela

1 Trata-se da Anamorphosis - Revista Internacional de Direito e Literatura, publicação da Rede Brasileira Direito e Literatura (RDL). Disponível em: <http://rdl.org.br/seer/index.php/anamps>.

2 Cabe referir, aqui, o postulado de Robert Cover (1983) de que qualquer ordem normativa não só não pode prescindir de força coercitiva como se funda em práticas organizadas de violência, legitimadas pelo sistema social, político e jurídico. 
dimensão criadora e lúdica, pela flexibilidade e constante renovação da linguagem, ${ }^{3}$ pelos efeitos de humanização e empatia que se mostra capaz de produzir, ${ }^{4}$ por sua natureza polifônica, ${ }^{\mathbf{5}}$ sua abertura para a plurissignificação ${ }^{\mathbf{6}}$ e para múltiplas possibilidades de interpretação ${ }^{7}$ - constitui importante recurso tanto para apurar a habilidade de leitura e desenvolver as competências de compreensão e interpretação de textos, essenciais à práxis jurídica, quanto para promover a ampliação do próprio horizonte de compreensão ${ }^{8}$ dos juristas e, portanto, a reflexão destes acerca dos fenômenos jurídicos e sociais.

Em vista disso, teóricos do Direito e Literatura têm defendido a ideia de que a aproximação entre as duas áreas possibilitaria o aprimoramento da formação jurídica e cívica - no qual reside o principal ponto de partida do movimento Law and Literature - ao favorecer, por intermédio de obras literárias, visão mais profunda, complexa e esclarecedora da realidade humana, do mundo e das relações sociais.

3 O modo como a linguagem é trabalhada nos textos literários e o efeito de estranhamento decorrente foram destacados, já no início do século XX, pelos formalistas russos, sobretudo nos estudos de Viktor Chklovski (1971) e Iuri Tynianov (1971), que empregaram o termo ostranenie para designar o processo de estranhamento ou desautomatização da linguagem e das formas literárias.

4 Não há como deixar de evocar aqui as palavras de Antonio Candido, quando afirma que a literatura constitui fator indispensável de humanização e define humanização como "o processo que confirma no homem aqueles traços que reputamos essenciais, como o exercício da reflexão, a aquisição do saber, a boa disposição para com o próximo, o afinamento das emoções, a capacidade de penetrar nos problemas da vida, o sentido da beleza, a percepção da complexidade do mundo e dos seres, o cultivo do humor. A literatura desenvolve em nós a quota de humanidade na medida em que nos torna mais compreensivos e abertos para a natureza, a sociedade, o semelhante" (CANDIDO, 2011, p. 182).

5 Aludimos, aqui, ao conceito que Mikhail Bakhtin (1988) formula ao definir romance polifônico como aquele em que se verifica a presença de múltiplas vozes, ideologicamente distintas, que propicia a expressão da diversidade social.

6 Em contraste com a univalência dos signos apresentada pela linguagem científica, os textos literários se caracterizam pela plurissignificação dos signos verbais, ou seja, por seu emprego ambíguo e metafórico, que resulta na abertura para mais de uma direção da carga semântica. O conceito de plurissignificação pode ser encontrado em Philip Wheelwright (1968).

7 Preferindo correr os riscos do excesso aos da omissão, cabe frisar que múltiplas possibilidades de interpretação não significam, como bem esclarece Umberto Eco $(1962 ; 1990)$, a admissibilidade de qualquer interpretação.

8 O conceito de horizonte, relativo ao papel da cultura na construção de sentido, após ter sido utilizado por Edmund Husserl (s. d.), encontra-se em Hans-Georg Gadamer (2003), conjugado à ideia de consciência histórica, e em Wolfgang Iser (1989; 1999), relacionado à implicação das disposições individuais do leitor os conteúdos da consciência, as intuições temporalmente condicionadas e a história de suas experiências na estruturação e significação que emergem no processo de leitura. 


\section{I ORIGEM E DESENVOLVimento}

De fato, os estudos em Direito e Literatura remontam ao início do século XX, e sua origem vincula-se ao contexto acadêmico estadunidense - no qual os textos literários são colocados a serviço da formação dos estudantes de direito e da sensibilização dos juristas - e ao nome de John Henry Wigmore, o qual, no artigo intitulado “A List of Legal Novels” (1908), oferece uma seleção de obras clássicas da literatura, sobretudo anglo-saxã, que abordam a temática jurídica. ${ }^{9}$

Entretanto, é somente a partir dos anos 1970 que Law and Literature começa a adquirir relevância como um dos movimentos de oposição ao formalismo jurídico - aos moldes do Critical Legal Studies (CLS) ${ }^{\mathbf{1 0}}$ - e se institui, teoricamente, com a publicação da obra The legal imagination, de James Boyd White (1973).

Em poucos anos, as pesquisas norte-americanas em Direito e Literatura ampliaram-se, do ponto de vista teórico, ao incorporarem o campo das ciências do texto, ${ }^{11}$ e propiciaram a abertura do direito para a interlocução com outras formas artísticas, dando origem ao movimento denominado Law and Humanities, que compreende estudos sobre Direito e Cinema, Direito e Música, Direito e Artes Plásticas...

Paralelamente, mas adquirindo características próprias, em diferentes países europeus, também despontam, a partir dos anos 1920-1930, ${ }^{12}$ e disseminaram-se, ao longo da segunda

9 Embora seja esse artigo a referência mais usual, no total, foram três as Listas publicadas por J. Wigmore. A primeira é de 1900 e contém 100 títulos; na segunda, de 1908, são explicitados os critérios de classificação das obras em quatro categorias e são oferecidos 377 títulos; e a terceira, de 1922, traz 121 títulos. Na década de 1970, Richard H. Weisberg $(1976 ; 1977)$ assumiu a tarefa de revisar as listas elaboradas por J. Wigmore e, apesar de não promover alterações substanciais quanto à definição das categorias, realoca algumas obras, acrescenta títulos do gênero dramático - como é o caso de Hamlet, Rei Lear e Otelo, de Shakespeare, bem como da peça teatral Entre quatro paredes, de Sartre - e, sobretudo, incorpora obras de escritores não contemplados nas listas de J. Wigmore, entre elas: $O$ homem revoltado e $A$ queda, de Camus; Crime e castigo e Os irmãos Karamazov, de Dostoiévski; O processo, de Kafka; Billy Budd, de Melville; e O céu é para todos, de Harper Lee. Para maiores informações sobre as alterações promovidas nas listagens publicadas ao longo de quase um século, remetemos ao artigo de Anne Simonin (2007), que oferece um estudo comparativo detalhado das quatro listas referidas aqui.

10 A expressão (em português, Estudos Críticos do Direito) é empregada para designar a escola teórica estadunidense pós-realista que, herdeira dos movimentos pelos direitos civis da década de 1960, surge oficialmente com a Conference on Critical Legal Studies, realizada em 1977, na University of Wisconsin-Madison, e, privilegiando o contexto social, tem como objetivo problematizar os mecanismos jurídicos que perpetuam a reprodução do poder e da dominação social.

11 Registre-se, aqui, que o papel desempenhado pela linguagem na representação, na expressão e na compreensão tanto de si quanto do mundo e das relações sociais é o elo que possibilita reunir diferentes formas comunicativas, gêneros textuais e modalidades discursivas - textuais ou não -, e abarcar os aparatos conceituais das ciências sociais, dos estudos literários, da análise do discurso, da semiótica e da comunicação.

12 Na Itália, destacam-se os trabalhos inaugurais de Ferrucio Pergolesi (1927) e de Antonio D’Amato (1936); na Suíça, Hans Fehr $(1923,1931,1936)$ amplia o campo de estudo para as relações entre direito 
metade do século $\mathrm{XX}^{13}$ e início do século XXI, ${ }^{14}$ estudos dedicados às relações entre Direito e Literatura.

No Brasil, embora o estabelecimento de uma produção contínua e sistemática seja bastante tardio, ${ }^{15}$ o estudo do Direito e Literatura vem ganhado espaço e visibilidade, ${ }^{16}$ ao

e arte; na Alemanha, Gustav Radbruch (1938), impulsionado pela relevância acadêmica que os estudos comparatistas adquirem nas primeiras décadas do século XX, analisa as concepções de direito nas diferentes culturas europeias, a partir de obras representativas de suas respectivas literaturas.

13 Na França e na Espanha, embora as primeiras publicações sejam da década de 1950 (SANSONE, 2001; MITTICA, 2015) e o tema passe a merecer maior atenção a partir dos anos 1980, é somente na virada do século XX para o século XXI que começam a surgir os trabalhos mais significativos, de José Calvo González (1996), de Philippe Malaurie (1997), de François Ost (2004) e de Pedro Talavera (2006).

14 Entre 2005 e 2009, consolida-se, na Universidade de Bergen (Noruega), a Nordic Network for Law and Literature, que reúne estudiosos das áreas do direito e da literatura ligados a instituições da Finlândia, Noruega, Suíça e Dinamarca (<http://littrett.uib.no/index.php?ID=Nettverk\&lang=Eng>); em 2008, é criada, na Itália, a Italian Society for Law and Literature (<http://www.lawandliterature.org/>), da qual participam pesquisadores de diferentes países europeus; e, mais recentemente, foi fundada, por inciativa de Jeanne Gaakeer (Erasmus University Rotterdam) e de Greta Olson (Justus-Liebig Universität Giessen), a European Network for Law and Literature (<https://www.uni-giessen.de/faculties/f05/engl/lit/research/eurnll>), junto à Law School de Rotterdam (Holanda), com o objetivo de promover e incrementar as investigações sobre Direito e Literatura no contexto europeu.

15 A primeira publicação brasileira em que começa a se delinear a relação entre o direito e a literatura é Machado de Assis e o problema penal, de Aloisio de Carvalho Filho (1959), seguida da obra A ciência jurídica e seus dois maridos, de Luis Alberto Warat (1985), que, preocupado com o ensino e a formação jurídica, sempre destacou a importância do papel criativo e crítico da literatura dentro de seus projetos pedagógicos. Entretanto, o marco inaugural de estudos sistemáticos é a obra Literatura e direito: uma outra leitura do mundo das leis, de Eliane Botelho Junqueira (1998), seguida da publicação de Direito e literatura: anatomia de um desencanto - desilusão jurídica em Monteiro Lobato, de Arnaldo Sampaio de Morais Godoy (2002).

16 Mesmo que a título meramente ilustrativo, cabe listar algumas das obras publicadas nos últimos anos: Direito \& Literatura: discurso, imaginário e normatividade, organizada por André Karam Trindade, Roberta M. Gubert e Alfredo Copetti Neto (2010); Encontros entre direito e literatura: ética, estética e política, organizada por Clarice B. da Costa Schöngen e Alexandre C. Pandolfo (2010); O mundo fora de prumo: transformação social e teoria política em Shakespeare, de José Garcez Ghirardi (2011); Direito, literatura e cinema: inventário de possibilidades, de Arnaldo Sampaio de Morais Godoy (2011); Direito penal na literatura: Shakespeare, Machado e outros virtuoses, de José O. Campos de Araújo (2012); Narração e normatividade: ensaios de direito e literatura, organizada por Judith Martins Costa (2012); Direito e literatura: da realidade da ficção à ficção da realidade, organizada por Lenio Luiz Streck e André Karam Trindade (2013); Direito e literatura: estudos jurídicos baseados em obras literárias da segunda metade do século XIX, organizada por Andres Botero e Líza Medina (2013); Direito, arte e literatura, organizada por Marcelo Galuppo, André Karam Trindade e Luiz C. Cancellier de Olivo (2014); Direito e literatura na virada do milênio, organizada por Sonja Arnold e Michael Korfmann (2014); Direito e literatura: por que devemos escrever narrativas?, organizada por Bernardo Nogueira e Ramon Mapa da Silva (2014); Os modelos de juiz: ensaios de direito e literatura, organizada por André Karam Trindade e Lenio Luiz Streck (2015). 
menos no circuito acadêmico do direito ${ }^{17}$ - como já assinalado -, e se caracteriza, especialmente, pelo

[...] destaque que confere à interdisciplinaridade, na medida em que se baseia no cruzamento dos caminhos do direito com as demais áreas do conhecimento - fundando um espaço crítico por excelência, através do qual seja possível questionar seus pressupostos, seus fundamentos, sua legitimidade, seu funcionamento, sua efetividade, etc. - - a possibilidade da aproximação dos campos jurídico e literário favorece ao direito assimilar a capacidade criadora, crítica e inovadora da literatura e, assim, superar as barreiras colocadas pelo sentido comum teórico, bem como reconhecer a importância do caráter constitutivo da linguagem. (TRINDADE; GUBERT, 2008).

\section{i.2 Principais CorRentes de investigação}

A instauração do paradigma da linguagem, que acarretou novas compreensões de representação, narrativa e discurso, foi essencial para que - paralelamente ao emprego dos textos literários, seja em prol da sensibilização, humanização e desenvolvimento do pensamento crítico dos atores jurídicos, seja para a contextualização ou problematização de temáticas relevantes para o direito - os conceitos literários e linguísticos ganhassem espaço no âmbito dos estudos jurídicos, dando origem a diferentes correntes de investigação no campo do Direito e Literatura, as quais se caracterizam por diferentes tipos de articulação entre as duas áreas e, sobretudo, por distintas ênfases e finalidades.

Inúmeras são as tipologias e classificações que têm sido propostas para abarcar tais articulações. Restringimo-nos, aqui, a apresentar as três correntes destacadas por François Ost (2004): direito da literatura, direito como literatura e direito na literatura.

A corrente do direito da literatura apresenta matiz essencialmente jurídico, pois se atém à legislação aplicável a obras literárias enquanto produto intelectual, e restringe-se às discussões jurídicas que, relativas a diferentes esferas do direito, incidem sobre as liberdades e garantias individuais - os limites e a liberdade de expressão face à censura e ao direito à intimidade -, os direitos autorais e a propriedade intelectual, os crimes de imprensa, as

17 Cabe registrar a existência de Grupos de Pesquisa em Direito e Literatura na UFPR, UFMG, PUCRS, UFSC, UniCEUB e IMED/RS; a realização de diferentes eventos sobre o tema, com destaque para o Colóquio Internacional de Direito e Literatura - CIDIL, que já teve quatro edições; a criação, em 2007, do GT "Direito, Arte e Literatura" no Conselho Nacional de Pesquisa e Pós-Graduação em Direito (Conpedi); a inclusão da disciplina Direito e Literatura na grade curricular de diversos cursos de Direito, seja na modalidade obrigatória, seja na optativa; o programa de TV Direito \&Literatura, já em seu nono ano de veiculação e que vai semanalmente ao ar, em rede nacional, pela TV Justiça; e a criação, em 2014, da Rede Brasileira Direito e Literatura (RDL). 
normas sobre o exercício profissional de escritor e políticas públicas voltadas para a leitura, entre outras. ${ }^{18}$ Assim, nessa corrente, estamos diante do texto literário como objeto da ciência jurídica.

Já o direito como literatura concentra-se em abordar as qualidades literárias dos textos jurídicos. Observa-se, aqui, uma inversão: os textos jurídicos tornam-se objeto da ciência literária, visto que conceitos oriundos deste campo - assim como dos campos da linguística, sobretudo da análise do discurso, e das ciências da comunicação - são adotados como instrumentos para a leitura e intepretação dos textos legais, em especial no que se refere às decisões judiciais.

Pertencem a essa corrente, as produções de dois dos fundadores do Law and Literature: James B. White, que aborda tanto a atividade criativa e interativa implicada na leitura e na interpretação dos textos jurídicos (1982) quanto o caráter retórico-argumentativo do direito, defendendo a inserção do direito no rol dos textos culturais que desempenham a função de fixar significados e de integrar os membros de uma comunidade por meio da linguagem e, consequentemente, dos ideais e dos valores por ela compartilhados (1985); e Benjamin Cardozo (1925), ao examinar as qualidades literárias dos textos jurídicos, com base no pressuposto de que o direito é literatura, e propor que sejam lidos e interpretados recorrendo-se ao aparato conceitual da teoria literária.

Igualmente representativos, apesar das particularidades de suas posturas teóricas, e inseridos no contexto da common law, são Robert Cover (1983), que apresenta a concepção do direito como conjunto de práticas narrativas e, partindo da noção de narratividade, propõe a sua interpretação do papel da jurisprudência constitucional estadunidense; e Ronald Dworkin (2001), tendo em vista a analogia que estabelece entre as atividades hermenêuticas exigidas na leitura dos textos jurídicos e literários, bem como a criação da metáfora do romance em cadeia para ressaltar a coerência e a integridade implicadas na atividade jurisdicional.

Os estudos mais recentes do direito como literatura, todavia, promovem uma aproximação do direito com o campo literário que ultrapassa a esfera analógica, guiada pela correspondência de aspectos linguísticos, estéticos e semióticos - relativos à compreensão dos textos jurídicos como produção literária ou produto cultural -, na medida em que as formulações investem de forma mais incisiva no caráter narrativo e, até, ficcional do direito (MARÍ, 2002; CALVO

18 Ilustram bem tal viés as questões que entraram em pauta no debate público e jurídico sobre a publicação de biografias não autorizadas. A Associação Nacional de Editores de Livros propôs ao Supremo Tribunal Federal a adoção da Ação Direta de Inconstitucionalidade (ADI), para permitir a publicação de biografias sem autorização do biografado. Em junho de 2015, o Plenário do Supremo Tribunal Federal, por unanimidade, julgou procedente a ADI 4815 e declarou inexigível a autorização prévia para a publicação de biografias (Disponível em: <http://redir.stf.jus.br/paginadorpub/paginador.jsp?docTP=TP\&docID=10162709>. Acesso em: 7 mar. 2016). 
GONZÁLEZ, 1996, 2008, 2013), formulações que - a nosso ver - ainda estão por merecer a devida atenção por parte dos especialistas em Semiótica e Narratologia. ${ }^{19}$

Por fim, temos a corrente do direito na literatura - a mais significativa no contexto acadêmico brasileiro -, que reúne os estudos dedicados à investigação das representações literárias da justiça e do direito, abarcando suas instituições, procedimentos e atores, bem como a temática concernente ao universo jurídico que se faz presente em textos literários, e no qual se verifica a ênfase em funções tradicionalmente atribuídas à literatura. ${ }^{\mathbf{2 0}}$

Os fundadores são John Wigmore (1900, 1908, 1922), que formula quatro critérios para identificar narrativas literárias que despertem o interesse e possam colaborar na formação dos juristas, instituindo um novo gênero literário - o romance jurídico -, e atribui a tais obras o estatuto de fonte de conhecimento do direito, tendo em vista a singular compreensão do fenômeno jurídico que elas podem oferecer; e, Frank Loesch (1926), que também aborda o conhecimento adquirido com textos literários e sua importância para a formação ética dos juristas.

Nessa corrente, merecem destaque, ainda, os trabalhos de Richard Weisberg (1984), para quem a literatura é uma via privilegiada de acesso à compreensão da natureza humana e das noções de direito e de justiça, ao dedicar-se à análise de obras literárias, concentrando-se no poder da linguagem e no exercício, ou não, da força argumentativa do discurso; e Richard Posner que, embora valorize os estudos interdisciplinares e a eles dedique parte de sua produção, não deixa de formular críticas à aplicação tanto de métodos da teoria literária a textos legais quanto de métodos de análise legal a narrativas literárias ao considerar que a relevância da literatura para o direito radica na representação da condição humana, dando especial

19 Cabe referir que, no contexto europeu, o primeiro passo nesse sentido foi dado pelas Faculdades Universitárias de Saint-Louis (Bruxelas), em outubro de 2000, com a criação de uma rede interdisciplinar que congrega diversos Centros de Pesquisa - o Centre de Recherche en Science Politique (CReSPo), o Centre de Recherches en Histoire du Droit et des Institutions (CRHIDI), o Centre de Recherche en Economie (CEREC), o Centre d'Étude du Droit de l'Environnement (CEDRE), o Centre d'Études Sociologiques (CES), o Centre interdisciplinaire de recherches en droit constitutionnel et administratif (CIRC), o Séminaire interdisciplinaire d'études juridiques (SIEJ) e o Séminaire interdisciplinaire de recherches littéraires (SIRL) -, dando origem ao espaço de interlocução entre estudiosos do direito e da literatura que propiciou, já no ano seguinte, a publicação de uma série de obras coletivas, sendo a primeira delas Lettres et lois: le droit au miroir de la littérature (OST et al., 2001).

Utilizando a taxonomia que Dino del Pino (1972) propõe ao abordar as funções da literatura, podemos estabelecer a distinção entre as correntes teóricas que acentuam a finalidade psicológica e individual da literatura, que congrega as funções catártica, de evasão da realidade, de fruição estética, de agente do conhecimento; e aquelas que realçam sua finalidade social, das quais merecem destaque, de um lado, as funções de caráter moral e pedagógico, em que a literatura se colocaria a serviço dos valores sociais compartilhados, e, de outro, a função de denúncia das mazelas e injustiças sociais e de problematização das questões humanas, que servem de diretriz para a denominada literatura engagée. 
atenção à temática da vingança, em Hamlet, Ilíada e Michael Kohlhaas; aos procedimentos judiciais, a partir das obras $O$ processo, A colônia penal, $O$ estrangeiro, $O$ mercador deVeneza e Medida por medida; e à problematização da aplicação da justiça, em Billy Budd e Irmãos Karamazov (POSNER, 1998).

E, para completar a lista de autores mais representativos do direito na literatura, devese referir Martha Nussbaum (2005; 2015), cujo interesse recai no papel da literatura para a compreensão da realidade - tendo em vista o fato de os textos literários representarem distintas dimensões da natureza humana, abordarem questões universais e favorecerem a imaginação e a empatia. Privilegiando a formação dos juristas, defende a ideia de que a racionalidade implicada no julgamento e na ponderação, além de habilidades argumentativas e lógicas, abarca, também, as capacidades imaginativa e empática, o que possibilita a apreciação sensível de situações humanas particulares e a contemplação da diversidade e da complexidade a elas inerentes.

Se as três correntes apresentadas permitem, de um lado, entrever a riqueza de que se revestem os estudos sobre Direito e Literatura, de outro, suscitam questões relativas aos distintos modos de como se dá a articulação entre os dois campos em cada uma delas e, consequentemente, aos graus de confluência de suas bases epistemológicas, aparatos conceituais e teóricos e pressupostos metodológicos.

O enfrentamento de tais questões é algo que se impõe, tendo em vista a necessidade tanto de que se estabeleçam - de forma explícita - os princípios, critérios e parâmetros que possibilitariam imprimir caráter efetivamente interdisciplinar aos estudos em Direito e Literatura quanto de que se promova o avanço rumo à produção de novos conceitos, métodos e procedimentos de investigação a serem operacionalizados nos estudos em Direito e Literatura, o que exigirá abordar o tema a partir das atuais concepções de inter-, multi- e transdisciplinaridade, cuja síntese pode ser encontrada nos trabalhos de Julie Thompson Klein (2005; 2011).

\section{Modelo metodológico}

Diante da concepção de que a narrativa literária constitui uma representação do homem e do mundo, fica evidente a importância, específica, que ela adquire como objeto capaz de suscitar temas de reflexão para o campo jurídico.

Entretanto, a apropriação e a aplicação do texto literário em outras áreas do conhecimento - seja com objetivo investigativo, seja com finalidade didática - requerem o domínio teórico-conceitual e metodológico adequado.

Nesse sentido, cabe evocar as condições - apontadas por Mohammed Allal Sinaceur que imprimem caráter interdisciplinar a investigações e pesquisas:

[...] a interdisciplinaridade, no sentido estrito do termo, se sempre existiu não leva a uma forma de conhecimento, portanto a uma prática científica, a não ser que a disciplina 
utilizadora (por consequência, o sujeito que a pratica) se aproprie do que ela precisa ao pensar seus problemas nos termos rigorosos da disciplina utilizada. Isso implica que a colaboração entre duas disciplinas exige dupla competência e a interdisciplinaridade, tantas competências quanto são as disciplinas que ela coloca em cooperação. (SINACEUR, 1977, p. 621).

Agregue-se ainda à reflexão, o alerta formulado por M. Paola Mittica - apesar da assimetria que se pode observar entre os dois campos -, ao considerar que:

Evidentemente, assim como é difícil para os juristas dominar, cientificamente, a interpretação de um texto literário - sem possuir os instrumentos próprios da análise literária -, pela mesma razão é aconselhável aos literatos recorrer aos estudiosos do direito para se orientarem acerca da compreensão dos fenômenos jurídicos, que exigem competências bastante sofisticadas. (MITTICA, 2015, p. 28, grifos nossos).

Não há dúvida de que o emprego dos instrumentos oferecidos pela teoria da literatura na análise e interpretação de textos literários pode favorecer uma leitura mais sofisticada, que ultrapassa a do leitor comum, e mais profícua, tendo em vista o fato de que o engessamento do senso comum é tão prejudicial no âmbito literário quanto o é no âmbito jurídico.

Entretanto, isso necessita ser ressaltado na medida em que, sendo a literatura um produto cultural, fica fácil ser induzido a simplificar sua decodificação, quando, pelo contrário, explorar a riqueza que um texto literário oferece exige a formação e a qualificação do leitor.

Assim, é no campo da teoria da literatura, mais especificamente da narratologia, que encontramos os subsídios necessários para a análise de obras literárias, e é aos seus pressupostos e conceitos ${ }^{\mathbf{2 1}}$ que devemos recorrer, preliminarmente, sempre que tivermos a intenção de desenvolver um trabalho ou uma pesquisa que envolvam textos literários.

Quanto aos principais pressupostos, há de se ter em conta que, desde os formalistas russos, não faz mais sentido estudar a obra a partir de informações relativas à vida de seu autor, pois se entende que o texto literário carrega sentidos que escapam às intenções de seu criador, embora atrelado à intencionalidade - no sentido husserliano ${ }^{22}$ - e vinculado à visão de mundo da época e da cultura em que foi produzido, seja para confirmá-la, seja para problematizá-la.

21 Como não é possível abarcar aqui, em profundidade ou em extensão, tais pressupostos e conceitos, serão evocados apenas aqueles entendidos como basilares para a compreensão da análise oferecida na sequência do texto.

22 A fenomenologia é introduzida, no campo da literatura, por Roman Ingarden (1965), que aplica as teses de E. Husserl (s. d.) na análise da obra literária, buscando demonstrar de que modo se dá a apreensão do fenômeno literário. 
O segundo pressuposto envolve as peculiaridades do uso da linguagem: ${ }^{23}$ se, nos demais tipos de discurso - e mesmo na fala cotidiana - , a linguagem busca expressar a objetividade dos seres e dos conceitos, do que decorre, de um lado, seu caráter de referência ao mundo exterior e, de outro, a prevalência da precisão e da exatidão linguísticas, o texto literário se caracteriza por expressar a subjetividade do enunciador e por explorar imagens, do que resulta o emprego da ambiguidade e da plurissignificação dos símbolos verbais, bem como a recorrência ao sentido metafórico, de tal modo que ela se destaca pela pluralidade de sentidos e de interpretações.

O terceiro pressuposto diz respeito ao fato de que a narrativa literária é uma criação imaginária e, portanto, o mundo que ela comporta corresponde a uma suprarrealidade, composta por elementos figurativos que estão a serviço de conteúdos temáticos.

Sinteticamente, a narrativa literária pode ser definida como relato ficcional, produzido por, no mínimo, um narrador que, assumindo determinada forma ou pessoa gramatical, institui lugares, personagens, objetos e ações, entidades engendradas no discurso, que passam a existir no universo diegético, embora possam ou não ter correspondência no mundo empírico (KARAM, 2008).

Em tal definição encontram-se elencados conceitos basilares da narratologia. O primeiro deles é o de narrador, aquele que relata os acontecimentos e que, sendo o enunciador do discurso, tem o poder de adotar diferentes pontos de vista ou focalizações ao narrar a história, pode fornecer ou omitir informações, ser imparcial ou intrusivo, ter ou não participado dos eventos por ele narrados.

De qualquer forma, é mediante o discurso enunciado pelo narrador - ou narradores que tomamos conhecimento do universo diegético, ${ }^{24}$ esse mundo ficcional que, tal qual o mundo empírico, compreende lugares, seres e objetos. Mas são as ações, ou seja, os eventos, que imprimem caráter dinâmico à narrativa literária, pois há nela um fluxo temporal que poderá ou não ser respeitado pelo narrador em seu relato: quando não o é, ocorrem as chamadas anacronias. Essa é uma das tantas estratégias narrativas empregadas em textos literários. O leitor comum, embora suscetível aos efeitos de tais estratégias, as desconhece e, por isso, muitas vezes, não sabe dizer ao certo por que a leitura de determinada obra lhe causou tanto impacto.

\section{I O CONTO SUJE-SE GORDO!}

A fim de demonstrar como se dá a instrumentalização de alguns conceitos narratológicos, bem como a sua utilidade para extrairmos do texto literário uma gama mais rica de elementos que

23 Tais peculiaridades são destacadas por Dino del Pino (1972) e por René Wellek e Austin Warren (1976).

24 O termo diegese e seus derivados são empregados por Gérard Genette (1983) para se referir ao universo espaço-temporal em que se desenvolve a história e os elementos que a compõem. 
podem ser objeto de reflexão e de discussão no campo do direito, foi escolhido o conto Suje-se gordo!, de Machado de Assis (1997), ${ }^{\mathbf{2 5}}$ considerando três aspectos: seu valor estético; os objetos do mundo representado; e, como consequência, a temática nele implicada.

A primeira tarefa que se impõe é fornecer os dados relativos à produção e à publicação do texto e oferecer o resumo da história: Suje-se gordo! foi publicado pela primeira vez em 1906, na coletânea intitulada Relíquias de casa velha, ${ }^{26}$ e a narrativa inicia com o relato do diálogo que o narrador teve com um amigo, durante o intervalo de uma peça teatral.

No primeiro parágrafo do texto, o narrador afirma que da peça mal guardou o título que seria $A$ sentença ou $O$ tribunal do júri -, mas que jamais esqueceu aquilo que, nessa oportunidade, o Amigo lhe contou.

No segundo parágrafo, o Amigo declara que sempre fora contrário ao júri, embora reconheça tratar-se de uma instituição liberal. Ele explica que a razão de sua repulsa era por, ao ser convocado como jurado, ter de condenar alguém e se justifica aludindo ao preceito bíblico: "não queiras julgar para não seres julgado” (p. 694-695).

Já a partir do terceiro parágrafo temos a reprodução do relato das experiências vividas pelo Amigo nas duas ocasiões em que votou pela condenação dos réus.

Em seu relato, o Amigo declara que, apesar de seus escrúpulos, participou de alguns julgamentos. Para sua sorte, muitas vezes, graças a falhas processuais, ele pôde votar pela absolvição: "Com efeito, os crimes não me pareceram provados; um ou dois processos eram mal feitos” (p. 695). Mas houve dois casos em que - apesar de sua inquietação - votou pela condenação dos réus.

O primeiro caso foi de um rapaz simples, de aparência humilde, que havia falsificado papéis que lhe renderam pouca quantia de dinheiro, duzentos mil-réis.

Ao contar esse julgamento, ele declara que o réu não negou a autoria do crime e descreve a atitude constrita do rapaz: "triste, a palavra surda, os olhos mortos, com tal palidez que metia pena" (p. 695).

A seguir, menciona as interpretações díspares que defesa e acusação ofereceram para tal atitude: "o promotor público achou nessa mesma cor do gesto a confissão do crime. Ao contrário, o defensor mostrou que o abatimento e a palidez significavam a lástima da inocência caluniada" (p. 695).

E, na sequência, comenta sobre o poder da linguagem no tribunal do júri:

25 Todas as citações do conto foram extraídas da edição que consta nas Referências. Limitamo-nos, portanto, a indicar a numeração da(s) página(s).

26 Cabe ressaltar que José Galante de Sousa (1955), na sua Bibliografia de Machado de Assis - considerada, ainda hoje, a mais autorizada fonte no que diz respeito a datas e locais de publicação dos textos de Machado de Assis -, traz a informação de que o conto Suje-se gordo! não havia sido publicado anteriormente. 
Poucas vezes terei assistido a debate tão brilhante. O discurso do promotor foi curto, mas forte, indignado, com um tom que parecia ódio, e não era. A defesa, além do talento do advogado, tinha a circunstância de ser a estreia dele na tribuna. [...] O discurso foi admirável, e teria salvo o réu, se ele pudesse ser salvo, mas o crime metia-se pelos olhos dentro. (p. 695).

Quanto aos eventos que ocorreram na sala secreta, ele narra que, mesmo tendo sido assegurados os votos necessários para a condenação do rapaz, um dos jurados, que era "cheio de corpo e ruivo, parecia mais que ninguém convencido do delito e do delinquente” (p. 695) e se chamava Lopes, insistira enfaticamente em defender seu voto:

O crime está mais que provado. O sujeito nega, porque todo o réu nega, mas o certo é que ele cometeu a falsidade, e que falsidade! Tudo por uma miséria, duzentos mil-réis! Suje-se gordo! Quer sujar-se? Suje-se gordo! (p. 695).

As palavras proferidas - Quer sujar-se? Suje-se gordo! - não são compreendidas imediatamente. Seu significado demora a ser apreendido:

Quando saí do tribunal, vim pensando na frase do Lopes, e pareceu-me entendê-la. "Suje-se gordo!" era como se dissesse que o condenado era mais que ladrão, era um ladrão reles, um ladrão de nada. (p. 696).

Muitos anos depois ocorre o segundo julgamento em que ele votou pela condenação. Nesse caso, o réu era um caixa do Banco do Trabalho Honrado que respondia pelo desvio de cento e dez contos de réis, uma grande quantia de dinheiro, equivalente a cento e dez milhões de réis. Para seu espanto, no tribunal, ele reconhece o acusado:

Era um homem magro e ruivo. Fitei-o bem, e estremeci; pareceu-me ver o meu colega daquele julgamento de anos antes. Não poderia reconhecê-lo logo por estar agora magro, mas era a mesma cor dos cabelos e das barbas, o mesmo ar, e por fim a mesma voz e o mesmo nome: Lopes. (p. 696).

Ele confessa que, buscando encontrar os traços registrados na memória e invadido por suas reminiscências, teve dificuldades em acompanhar o interrogatório, mas relata o comportamento do réu:

Lopes negava com firmeza tudo o que lhe era perguntado, ou respondia de maneira que trazia uma complicação ao processo. Circulava os olhos sem medo nem ansiedade; não sei até se com uma pontinha de riso nos cantos da boca. (p. 696). 
Segundo ele, durante todo o julgamento, o réu manteve-se "com o rosto alto, mirando o escrivão, o presidente, o teto e as pessoas que o iam julgar” (p. 697), e tal comportamento é novamente objeto de interpretações divergentes:

Todos esses gestos do homem serviram à acusação e à defesa, tal como serviram, tempos antes, os gestos contrários do outro acusado. O promotor achou neles a revelação clara do cinismo, o advogado mostrou que só a inocência e a certeza da absolvição podiam trazer aquela paz de espírito. (p. 697).

Durante os debates, ele reflete sobre a "fatalidade de estar ali, no mesmo banco do outro, este homem que votara a condenação dele [...] Aquele que julgava outrora, era agora julgado também" (p. 697-698), e isso o leva a lembrar-se tanto do preceito bíblico - Não queirais julgar, para que não sejais julgados - quanto da máxima do próprio Lopes: Suje-se gordo!

Tais lembranças vêm consolidar sua percepção:

Vi que não era um ladrão reles, um ladrão de nada, sim de grande valor. O verbo é que definia duramente a ação. "Suje-se gordo!" Queria dizer que o homem não se devia levar a um ato daquela espécie sem a grossura da soma. A ninguém cabia sujar-se por quatro patacas. Quer sujar-se? Suje-se gordo! (p. 698)

Quanto à decisão dos jurados, ele reafirma ter votado pela condenação e, sugerindo que alguns jurados teriam desconsiderado as provas que constavam nos autos, informa o veredito:

Posso dizer-lhe aqui em particular que votei afirmativamente, tão certo me pareceu o desvio dos cento e dez contos. Havia, entre outros documentos, uma carta de Lopes que fazia evidente o crime. Mas parece que nem todos leram com os mesmos olhos que eu. Votaram comigo dois jurados. Nove negaram a criminalidade do Lopes, a sentença de absolvição foi lavrada e lida, e o acusado saiu para a rua. (p. 698, grifo nosso).

No fim do relato, confessa que o resultado da votação o fez duvidar de seu discernimento e que ainda sente uns repelões de consciência diante da possibilidade de haver cometido um erro de julgamento, mas o consola saber que, se Lopes era inocente, seu voto não foi suficiente para condená-lo. E conclui a narrativa aludindo novamente à máxima que dá origem ao título do conto:

O melhor de tudo é não julgar ninguém para não vir a ser julgado. Suje-se gordo! suje-se magro! suje-se como lhe parecer! o mais seguro é não julgar ninguém... (p. 698). 


\subsection{O PERCURSO ANALÍTICO-INTERPRETATIVO}

Tendo em vista o objetivo de fornecer um modelo de percurso analítico-interpretativo, serão demarcadas e descritas suas diferentes etapas - bem como explicitados seus respectivos procedimentos -, embora reconhecendo a interpenetração existente entre elas.

Do ponto de vista metodológico, tal percurso irá privilegiar o fato de que a obra literária, por ser uma representação, comporta tanto o mundo representado quanto a sua função de representar (PINO, 1998). O mundo representado compreende os eventos narrados e o contexto em que eles se inserem; já a função de representar apresenta duplo vetor, pois, de um lado, tem pontos de ancoragem no contexto histórico de sua produção, ao qual se vincula, e, de outro, é suscetível à atualização, tanto do ponto de vista da produção quanto da recepção.

O resumo oferecido, naturalmente, já realiza e antecipa - do ponto de vista analítico a seleção dos elementos que, extraídos no processo de leitura, se pretende examinar. A análise de tais elementos, que compõem o mundo representado, é o primeiro procedimento a ser realizado e propicia identificar o tema ou temas que neles possam estar implicados.

O contexto dos eventos apresentados no conto de Machado pode ser definido a partir de referências espaciais explícitas, que permitem situá-los na cidade do Rio de Janeiro - o Teatro de São Pedro de Alcântara, o antigo Aljube, localizado na Rua dos Ourives, princípio da Ladeira da Conceição, a Rua de São Pedro -, bem como de alguns índices temporais que possibilitam inferir a cronologia dos eventos: o advogado de defesa do primeiro júri faleceu em 1865, dois anos após o julgamento, que ocorrera, portanto, em 1863; o segundo júri aconteceu muito tempo depois; a conversa entre os dois amigos, obviamente posterior aos dois julgamentos, não é possível determinar, mas sabe-se que persistem, naquele que serviu como jurado, os repelões de consciência por ter votado pela condenação; e, por fim, o relato do diálogo entre os dois amigos - que diz respeito, temporalmente, ao momento da enunciação e cujo conteúdo constitui o conto em si - inicia com a indicação de que o encontro foi uma noite, há muitos anos.

Pode-se observar, portanto, que o conto Suje-se gordo! se estrutura a partir de duas situações narrativas: o relato da conversa entre os dois amigos, que adquire, a princípio, caráter meramente introdutório; e o relato dos dois julgamentos e das impressões deles decorrentes.

O segundo relato constitui o cerne da narrativa e se concentra na representação do tribunal do júri, na qual são evidenciados, de um lado, os procedimentos adotados durante as sessões de julgamento e, de outro, as convicções, as percepções e a atuação do jurado. Em relação aos procedimentos, tem-se a descrição do rito empregado no tribunal do júri ${ }^{27}$ a menção

27 Os elementos que o conto oferece do rito processual empregado no tribunal do júri podem ser matéria de interesse para o estudo histórico e compreendem: o interrogatório do acusado, a leitura das peças comprobatórias, o depoimento das testemunhas, o debate (acusação, defesa, réplica e tréplica), o resumo dos debates, a leitura e entrega dos quesitos, a votação dos doze jurados na sala secreta (decisão por maioria), a entrega da decisão, a sentença e a possibilidade de apelação. Os aspectos que diferem do rito atual são 
a falhas processuais, a caracterização dos crimes sob julgamento. ${ }^{\mathbf{2 8}}$ No que se refere ao jurado, duas são as convicções que ele explicita: o tribunal do júri é uma instituição liberal; o melhor é não ter de julgar. Quanto às suas percepções - favorecidas pelo relato autodiegético -, elas incidem sobre o desempenho do promotor e do advogado de defesa, sobre os efeitos provocados pelos comportamentos e posturas dos dois réus e sobre a conduta dos demais jurados. Já a sua atuação como jurado, que transparece no relato, exige que se relacionem suas atitudes com os sentimentos que ele expressa, do que resultam: os escrúpulos em condenar alguém e o peso da subjetividade implicada no ato de julgar.

Os aspectos destacados propiciam identificar as questões jurídicas que o texto suscitou na leitura aqui proposta e possibilitam afirmar que, por meio dos elementos figurativizados no conto, Machado de Assis - e só nessa esfera cabe aludir ao autor, pois as ideias dentro do texto são de responsabilidade estrita do narrador ou narradores - problematiza o tribunal do júri e a crença de que o instituto assegura a realização da justiça.

Cabe, agora, realizar o segundo procedimento - mediante o qual se ingressa na esfera interpretativa -, que consiste em investigar o sentido intrínseco ao texto, sob a perspectiva do contexto histórico de sua produção, de modo a avaliar em que medida a crítica que Machado de Assis estaria dirigindo ao tribunal do júri se vincula e reflete tal contexto.

Em outras palavras, trata-se de abordar o surgimento e a evolução do tribunal do júri e verificar, privilegiando o exame dos dispositivos legais em vigor tanto no Segundo Império -

a alteração da ordem em que se realizam alguns dos procedimentos - o interrogatório do réu precedia a leitura das peças e a oitiva das testemunhas ocorria após a leitura -; o resumo dos debates que o juiz deve oferecer aos jurados e o número de doze jurados. Tais discrepâncias não resultam da criação artística; correspondem ao que previa a legislação da época em que, no conto, se situam os julgamentos. A inclusão do resumo dos debates nos procedimentos do tribunal do júri remonta ao disposto no art. 32, da Lei de 20 de setembro de 1830 (BRASIL, 1830a) - o qual determinava que o juiz de direito, "achando a causa em estado de ser decidida", deveria resumir "com a maior clareza possível toda a matéria da acusação, e da defesa, e as razões expedidas pró, e contra” - e foi mantido tanto pelo Código de Processo Criminal de Primeira Instância, de 29 de novembro de 1832 (BRASIL, 1832), quanto pela Lei n. 261, de 3 de dezembro de 1841 (BRASIL, 1841), que reformou o Código do Processo Criminal, só sendo eliminado a partir da entrada em vigor do Decreto n. 848, de 11 de outubro de 1890 (BRASIL, 1890b), que fixa a organização da Justiça Federal e faculta às legislações locais definirem as prescrições e os regulamentos a serem adotados para o tribunal do júri. Já o número de doze jurados era estipulado pelo art. 259 do Código de Processo Criminal de Primeira Instância, de 29 de novembro de 1832 (BRASIL, 1832) e só sofreu alterações com a promulgação da Constituição de 1946 (BRASIL, 1946), que estabeleceu a obrigatoriedade de que o número de membros do corpo de jurados seja ímpar. Atualmente, o art. 447, da Lei n. 11.689, de 9 de junho de 2008 (BRASIL, 2008), regulamenta que o Conselho de Sentença seja composto por 7 jurados.

28 O crime do primeiro julgamento é o de falsificação; o do segundo, de falsidade e desvio de dinheiro. Ambos não são, hoje, da competência do júri, cuja atuação se limita - de acordo com o disposto no art. $5^{\circ}$, inc. XXXVIII, alínea d, da Constituição de 1988 - aos crimes dolosos contra a vida (BRASIL, 1988). 
momento em que se situam os eventos narrados ${ }^{29}$ - quanto no início do período republicano, se a legislação brasileira, em confronto com a realidade social do Brasil, favorece que o tribunal do júri adquira, de fato, o estatuto de instituição liberal e, por consequência, enquanto tal assegure a realização da justiça.

A adoção do tribunal do júri no Brasil se vincula ao prestígio que o instituto alcançou no pensamento liberal em voga na Europa e nos Estados Unidos, desde as últimas décadas do século XVIII, e que pode ser comprovado pela sua inclusão na Constituição dos Estados Uni$\operatorname{dos}^{30}$ e na legislação francesa. ${ }^{31}$

De fato, como ressalta o historiador do direito John Gilissen (2003, p. 501), nos países europeus, a partir do século XIX, “O estabelecimento do júri era reclamado pela opinião liberal como garantia da liberdade e do progresso e como elemento fundamental do liberalismo burguês".

No Brasil, é sob a influência do pensamento liberal de José Bonifácio que o príncipe regente, D. Pedro de Alcântara, institui o tribunal do júri ainda no período colonial. Por meio do Decreto de 18 de julho de 1822 (BRASIL, 1822), foi criada a figura dos juízes de fato, para o julgamento dos crimes de abuso de liberdade de imprensa, e estipulado que o tribunal do júri seria composto por oito de "24 cidadãos escolhidos de entre os homens bons, honrados, inteligentes e patriotas”, cabendo ao juiz de direito aplicar a pena.

Para a compreensão da exigência definida no dispositivo, convém recorrer ao sentido que a expressão homem bom adquire no contexto colonial. Segundo Raymundo Faoro:

29 Há, no texto, a referência explícita ao local em que teria ocorrido os dois julgamentos: ambos no prédio do antigo Aljube. Existem, também, indicações temporais que permitem situar o primeiro julgamento no ano de 1863, como já destacado. Quanto ao segundo julgamento, embora o conto não forneça informações precisas sobre quando ele teria se realizado, é possível inferir - recorrendo a dados históricos - que não fosse após 11 de janeiro de 1884, visto que a partir dessa data o tribunal do júri da cidade do Rio de Janeiro passou a funcionar em uma das salas da Câmara Municipal, conforme noticiado no jornal Gazeta de Notícias, edição n. 11, 11 de janeiro de 1884. Apesar dos riscos que se correm ao forjar paralelos entre o universo ficcional e o mundo empírico, tal inferência é plausível se considerarmos que, ao introduzir no conto índices espaciais oriundos da realidade exterior, os quais contribuem para o efeito de real (BARTHES, 1984), Machado de Assis delimita - ao menos para o leitor que lhe é contemporâneo - as coordenadas espaço-temporais dos eventos narrados.

30 A inclusão deu-se por meio das Emendas V, VI e VII, que fazem parte da United States Bill of Rights e entraram em vigor em 15 de dezembro de 1791 (UNITED STATES OF AMERICA, 2017).

31 Na França, o tribunal do júri é uma das conquistas promovidas pela Assembleia Constituinte de 17891791, tendo sido instituído pela Lei de 16-29 setembro de 1791 e pela Lei de 29 de setembro-21 de outubro de 1791, que organizam o procedimento criminal e atribuem papel de destaque ao júri popular (FRANCE, 1835). 
Na verdade, o escopo íntimo da superioridade institucional do homem bom será o mesmo que inspira os conselhos portugueses: inscrever os proprietários e burocratas em domicílio na terra, bem como seus descendentes, nos Livros da Nobreza, articulando-os, desta sorte, na máquina pública e administrativa do império. (FAORO, 2001, p. 214).

Com a Proclamação da Independência, é outorgada a Constituição Política do Império, de 25 de março de 1824 (BRASIL, 1824), e o tribunal do júri adquire o estatuto de previsão constitucional, sendo-lhe atribuída competência para atuar nas esferas criminal e cível (art. 151). ${ }^{32}$ Qualificada como liberal, a Constituição de 1824, além de conceder aos cidadãos analfabetos o direito de voto - o que, em si, não significava o exercício da cidadania -, assegurava o direito à educação primária e gratuita a todos os cidadãos (art. 179, item 32) e determinava: “a lei será igual para todos, quer proteja, quer castigue, e recompensará em proporção dos merecimentos de cada um” (art. 179, item 13), princípio de isonomia que, no entanto, coexistia com a legitimação da escravatura.

Por meio da Lei de 20 de setembro de 1830 (BRASIL, 1830a), sobre o abuso de liberdade de imprensa, foram criados o jury de accusação e o jury de julgação, ${ }^{33}$ fixada a condição de eleitor para atuar como jurado (art. 16) e definida a Fórmula do Juramento: "Juro pronunciar bem, e sinceramente nesta causa; haver-me com franqueza, e verdade, só tendo diante de meus olhos Deus, e a Lei, e proferir o meu voto segundo a minha consciência" (art. 21, grifo nosso).

Cabe esclarecer que a exigência de ser eleitor não implica modificações, uma vez que tal condição estava vinculada aos procedimentos adotados na eleição dos Deputados, de modo que só poderia ser jurado quem tivesse renda líquida anual de duzentos mil réis.

Observa-se, assim, que a passagem de Colônia portuguesa a Império não trouxe alteração significativa na composição do corpo de jurados, visto que o critério de homens bons, considerando o que o termo significava, foi substituído pelo valor estipulado de renda anual líquida.

Constata-se, também, na fórmula do juramento, que Deus figura antes da Lei e que os preceitos religiosos, portanto, não só encontram amparo como antecederiam os princípios legais, na deliberação segundo a própria consciência.

Após a elaboração do Código Criminal do Império, de 16 de dezembro de 1830 (BRASIL, 1830 b) - que, curiosamente, contrasta com a previsão constitucional de isonomia, pois considerava crime justificável e não punível o mal decorrente de "castigo moderado, que os pais derem a seus filhos, os senhores a seus escravos, e os mestres a seus discípulos" (art. 14, $\S 6^{\circ}$ ) -, surge o Código de Processo Criminal de Primeira Instância, de 29 de novembro de 1832

32 A atuação do Tribunal do Júri na esfera civil, que dependia de lei especial, nunca se concretizou.

33 O júri de acusação tinha a função de examinar a admissibilidade acusatória; o júri de julgamento, a de analisar o mérito da causa, deliberando sobre a condenação ou a absolvição do réu. 
(BRASIL, 1832), que definia a organização judiciária, mantendo o júri de acusação e o júri de julgamento, bem como a fórmula do juramento, prescrevendo a qualificação para ser jurado - "São aptos para serem Jurados todos os cidadãos, que podem ser Eleitores, sendo de reconhecido bom senso e probidade" (art. 23, grifo nosso) - e fixando os requisitos para a condição de eleitor, todos em sintonia com a previsão constitucional: (a) ser homem; (b) ter mais de 25 anos, podendo ser 21 anos, no caso de chefes de família, oficiais militares, bacharéis formados, empregados públicos, clérigos e daqueles com independência financeira; (c) ter renda anual líquida de 200 mil réis, por bens de raiz, indústria, comércio ou emprego (art. 94).

Por sua vez, a Lei n. 261, de 3 de dezembro de 1841 (BRASIL, 1841), que reformou o Código do Processo Criminal, introduziu modificações substanciais na organização judiciária e, também, no tribunal júri, sendo extinto o júri de acusação. Quanto às condições para ser jurado, além de ser eleitor, é incluída a exigência de saber ler e escrever e estipulada a renda anual líquida de 400 mil réis para os cidadãos dos Termos das cidades do Rio de Janeiro, Bahia, Recife e São Luiz do Maranhão; 300 mil réis, dos Termos das outras cidades do Império; e 200 mil réis em todos os demais Termos, devendo ser dobrados os valores se o rendimento provier do comércio ou da indústria (art. 27, grifo nosso).

Note-se que não só se eleva o valor da renda líquida anual dos possíveis jurados das principais capitais do Império, como ele é vinculado à fonte da renda. Ou seja, aqueles que Machado de Assis, tantas vezes em seus textos, costuma denominar "capitalistas", pois possuem capital e vivem de suas rendas - e que, naturalmente, corresponderiam aos herdeiros das famílias abastadas da Corte portuguesa -, são beneficiados. Já dos “novos ricos”, cujos proventos eram procedentes do comércio e da indústria, era exigido o dobro do valor.

É nesse contexto histórico que Machado situa os dois julgamentos do conto, considerando que o primeiro deles teria ocorrido em 1863 e o segundo, antes de 11 de janeiro de 1884. ${ }^{34}$ Em suma, a lei será igual para todos; o jurado deliberará segundo sua consciência, só tendo diante de si Deus e a Lei; e a condição para fazer parte do corpo de jurados, na cidade do Rio de Janeiro, era: (a) ser homem; (b) ter mais de 25 anos, podendo ser 21 anos, obedecidas certas circunstâncias; (c) saber ler e escrever; e (d) ter renda anual líquida de 400 mil réis, por bens de raiz ou proveniente de emprego, ou renda anual líquida de 800 mil réis, se oriunda da indústria ou do comércio.

Além da explicitação dos dispositivos legais, para complementar o panorama social, é possível recorrer a registros históricos documentais que comprovam o descrédito em relação ao funcionamento do tribunal do júri.

Encontramos na Gazeta de Notícias - um dos principais jornais do Rio de Janeiro e que circulou de 1875 a 1942 -, na edição do dia 12 de setembro de 1884, um texto não assinado que tece duras críticas: 
Quem acompanha de perto e vê com espírito desprevenido as decisões do tribunal do júri, com dolorosa surpresa observa nelas uma tal falta de harmonia que, por muito respeito que lhe mereça a liberal instituição, não se pode furtar a sérios reparos que provocam os seus julgamentos.

Ninguém ignora a amplitude deixada pelo código à consciência dos Srs. juízes de fato; os jurados podem afirmar ou negar a existência de qualquer delito, por mais ou menos provado que esteja ele.

Entretanto, no exercício das suas melindrosas atribuições, tão graves e tão sérias, o júri, se pode usar, não deve abusar daquela faculdade que a lei lhe confere, porquanto esse abuso determina necessariamente no espírito público, senão a certeza da injustiça, pelo menos a dúvida quanto ao critério dos julgamentos.

A seguir, a mesma matéria faz alusão a dois casos julgados naquele mês. O primeiro réu - que já havia sido absolvido e, após apelação acatada, estava sendo julgado novamente era acusado de ofensas físicas graves e foi novamente absolvido, por sete votos; o segundo réu, acusado de pequeno furto, foi condenado por unanimidade, sendo sentenciado a oito anos de prisão com trabalhos forçados.

Ao expressar a sua indignação com a disparidade dos vereditos, o autor do texto reflete, também, sobre o valor do bem que estaria ou não sendo tutelado nas decisões - “Aqui, nem o júri tem desculpa do que fez na natureza dos delitos: se é verdade que o ataque à propriedade é daqueles crimes que maior alarme produzem na sociedade, ainda maior é o alarme produzido pelo ataque à pessoa do cidadão”, e, na sequência, evoca o caso que havia sido julgado no dia anterior:

O réu foi preso em flagrante: muitas pessoas viram e atestaram o fato; as testemunhas são absolutamente concordes nos depoimentos que fizeram; o Sr. advogado não contrariou a existência de delito, e o Sr. promotor provou-o exuberantemente.

E depois disso o que fez o júri? negou unanimemente o delito, afirmando com todas as formalidades da lei que o réu não cometeu tal crime! [...]

Negar no plenário o que ninguém contestou ou que é afirmado por testemunhas arroladas, o que foi praticado em lugar público e visto por muita gente, isto pode ser benevolência, pode ser coisas de bom coração e sentimentalismo, mas não é com certeza compatível com a seriedade do tribunal.

A proximidade entre as situações reais descritas no texto jornalístico e as situações fictícias oferecidas no conto de Machado de Assis é mais do que evidente, especialmente no que diz respeito à possibilidade de os jurados, ao votarem segundo as suas consciências e movidos pelo bom coração e sentimentalismo, negarem o delito, apesar das provas produzidas.

Tal proximidade condiz com a estética realista que Machado imprime, especialmente, nas 
narrativas que se incluem na segunda fase de sua produção e resulta da sua preocupação em representar a realidade social brasileira. Acrescente-se, ainda, que, embora os eventos do conto se situem no período do Império, sua publicação ocorre em 1906, de tal modo que a representação oferecida do tribunal do júri encontraria correspondência também no contexto republicano e evidenciaria, portanto, que a troca de regime político não teria promovido grandes alterações. Aliás, como destaca Moraes (2010), quando consideramos o título da coletânea em que o conto vem publicado, é possível supor que o funcionamento do tribunal do júri se inscreveria, na óptica de Machado de Assis, entre as relíquias que o Império havia deixado de herança para a República.

Essa hipótese impõe retomar a descrição histórica dos dispositivos legais que tratam do tribunal do júri. Antecipando a primeira Carta republicana, o Decreto n. 847, de 11 de outubro de 1890 (BRASIL, 1890a), que institui o Código Penal dos Estados Unidos do Brasil, menciona o tribunal do júri (art. 405, $\S 2^{\circ}$ ); o Decreto n. 848, também de 11 de outubro de 1890 (BRASIL, 1890b), que tratava da organização da Justiça Federal, cria o júri federal e dispõe que deverá ser composto por "doze juízes, sorteados dentre trinta e seis cidadãos" (art. 41, grifo nosso); e o Decreto n. 1.030, de 14 de novembro de 1890 (BRASIL, 1890c), que organiza a justiça do Distrito Federal - no caso, a cidade do Rio de Janeiro -, define a qualificação exigida para os juízes de fato: "cidadãos de 21 a 65 anos de idade, que souberem ler e escrever, e tiverem as qualidades de eleitor" (art. 40).

Já a Constituição da República dos Estados Unidos do Brasil, de 24 de fevereiro de 1891 (BRASIL, 1891), que pode ser considerada inovadora para os padrões da época, não só preserva a instituição do júri como lhe outorga o estatuto de garantia individual ${ }^{35}$ e prescreve que "Todos são iguais perante a lei” (Seção II, art. 72, $\S 2^{\circ}$ ). Quanto às condições para ser eleitor, que nos interessam particularmente pela sua vinculação com as exigências para ser jurado, elas vêm definidas no art. 70: ser cidadão maior de 21 anos, excluídos os mendigos, os analfabetos, os soldados que não sejam alunos de escolas militares de ensino superior, os religiosos que tenham renunciado à liberdade individual.

O Decreto Federal n. 3.084, de 5 de novembro de 1898 (BRASIL, 1898a) - que vem consolidar as alterações promovidas pela Lei Federal n. 221, de 20 de novembro de 1894 (BRASIL, 1894) e pela Lei Federal n. 515, de 3 de novembro de 1898 (BRASIL, 1898b) -, constituirá, durante décadas, o Código de Processo Civil e Criminal da Justiça Federal, que reconhece o tribunal do júri como órgão do Poder Judiciário (art. $1^{\circ}$ ) e determina que o júri federal seja composto por "12 juízes sorteados dentre 48 cidadãos qualificados jurados na capital do Estado onde houver de funcionar o tribunal e segundo as prescrições e regulamentos estabelecidos pela legislação local” (art. 80).

35 Destaque-se que o dispositivo que institui o tribunal do júri foi inserido no Título IV "Dos cidadãos brasileiros", Seção II "Declaração de Direitos". 
A sintética fórmula adotada na Constituição de 1891 - "É mantida a instituição do júri” (art. 72, §31) - aliada ao fato de atribuir aos estados da Federação a competência para, observados os princípios nela instituídos, legislar sobre a sua própria divisão e organização judiciárias deu origem a díspares interpretações.

Segundo Athos Vellozo (1952), as discussões só cessaram quando, em Acórdão de 7 de outubro de 1899, o Supremo Tribunal Federal manifestou-se sobre o tema e fixou as características do tribunal do júri. Quanto à composição, definiu que os jurados seriam cidadãos qualificados, periodicamente, pelas autoridades designadas pela lei, e que o conselho de julgamento seria composto pelo número fixado de jurados, escolhidos à sorte e sujeitos à recusa, desde que esta não inviabilizasse a sessão. Quanto ao funcionamento, foram estipuladas: a incomunicabilidade dos jurados com pessoas estranhas ao conselho, para preserválos de sugestões alheias; a produção pública e perante o conselho das alegações e das provas da acusação e da defesa; a atribuição de cada jurado julgar segundo a sua consciência; e a isenção de responsabilidade pelo voto emitido, fosse ele a favor ou contra o réu.

A essa altura, já temos dados suficientes para avaliar a legislação sobre o tribunal do júri na época da produção do conto, bem com a realidade social que a narrativa possibilita entrever. O princípio da igualdade de todos perante a lei é direito garantido pela Constituição de 1891 - o que não significa que os privilégios das classes superiores não se mantivessem, como o comprovam as exigências para ser jurado.

É bem verdade que a qualificação dos jurados já não é definida pela renda. Na cidade do Rio de Janeiro, à época Distrito Federal do Brasil, a condição - como já indicado anteriormente - era ser cidadão maior de 21 anos, excluídos os mendigos, os analfabetos, os soldados que não fossem alunos de escolas militares de ensino superior e os religiosos que tivessem renunciado à liberdade individual. Aparentemente, um sensível progresso, não fosse o fato de que, segundo o Censo de 1890, ${ }^{36}$ a taxa de analfabetismo no Brasil atingia, na época, a cifra de $85,2 \%$.

Sendo assim, por óbvio, os jurados pertenciam à elite econômica - seja no período do Império seja no da Primeira República - que, quando eram convocados, muitas vezes, preferiam forjar justificativas ou pagar a multa por não comparecimento do que abdicar de seus afazeres. Aliás, essa seria a razão pela qual o júri de acusação havia sido extinto, ainda em 1841.

A esse respeito, em sua Conferencia sobre o jury, ${ }^{37}$ proferida em setembro de 1905, Raphael Corrêa da Silva, advogado e professor catedrático "lente" da Faculdade de Direito de São Paulo, destaca que

36 Utilizamos aqui os dados do Censo de 1890, porque o Censo de 1900 não foi concluído (OLIVEIRA, 2012).

37 O fato de a conferência ter sido integralmente transcrita no jornal O Commercio de São Paulo, nas edições de 27, 28 e 29 de setembro de 1905, antes de ser publicada na Revista da Faculdade de Direito de São Paulo, demonstra o interesse da opinião pública pelo tribunal do júri. 
O júri de acusação era um peso insuportável à nova sociedade. País de terras vastas, com escassa população, a reunião de jurados para dois atos distintos não se podia realizar senão com grande sacrifício dos cidadãos qualificados para isso. As distâncias, a dificuldade de transporte, a inclemência das estações, faziam com que os cidadãos de vida rural preferissem pagar as multas impostas às suas faltas a abandonar seus interesses e famílias por muitos dias. (SILVA, 1905, p. 25).

Além disso, embora conceba o tribunal do júri como um "baluarte da liberdade”, o eminente professor refere que o instituto é alvo de ácidas críticas - "O júri decaído, o júri relaxado, o júri corrompido, o júri mal escolhido, são chascos que ouvimos todos os dias" (SILVA, 1905, p. 27) - e defende que os crimes menores sejam excluídos da alçada do tribunal do júri, de modo a "realçar a nobreza do julgamento popular, aliviando os cidadãos qualificados de grande soma de trabalhos" (SILVA, 1905, p. 32).

De fato, a formação do corpo de jurados e, por consequência, do conselho de sentença, era problemática, uma vez que o não comparecimento dos cidadãos qualificados e convocados poderia ser considerado prática constante. Uma breve pesquisa na Gazeta de Notícias é suficiente para comprovar tal afirmação; para ilustrá-la, basta citar o pregão publicado na edição do dia 28 de maio de 1898, no referido jornal:

\section{JURY}

\section{5 a SESSÃO ORDINÁRIA}

Não funcionou ontem o tribunal por falta de número legal de jurados.

Foram designados para hoje os réus João Antônio Esteves, por tentativa de roubo, e Antônio Martins da Silva Passos, por crime de roubo.

Ontem foi a quarta vez que compareceu para ser julgado o réu João Antônio Esteves, sem que

o Tribunal do Júri reunisse número legal, o que torna em prejuízo aos demais processos sujeitos àquele julgamento. (grifos nossos).

Por outro lado, como destaca Thomas Flory (1986), já no império, a participação no júri era alvo de contrariedade e de resistência por parte da elite cultural, que buscava, de todas as formas evadir-se, deixando a tarefa a cargo dos mais incultos e com menos discernimento.

Tal quadro não teria se alterado com o advento da República, como evidencia o texto publicado também na Gazeta de Notícias, edição n. 125, de 5 de maio de 1900, de autoria do Dr. Souza Lima:

Muito sedutora é em princípio a teoria do julgamento do povo pelo povo; na prática, porém, os resultados são os mais disparatados e comprometedores, porque nem toda gente que pela lei tem assento no tribunal do júri possui as condições morais e intelectuais necessárias para julgar a criminalidade de seus pares, através das discussões jurídicas em 
que se empenham o ministério público e os advogados de defesa. Aqueles que pela sua instrução e probidade mais poderiam auxiliar à justiça, esses se eximem de comparecer ao trabalho penoso do júri, o que facilmente alcançam por meios conhecidos.

Do ponto de vista jurídico, o mais questionável parece ser a eficácia do tribunal do júri na realização da justiça, tendo em vista os efeitos das prerrogativas outorgadas ao corpo de jurados de julgar segundo a consciência e de isenção de responsabilidade pelo voto emitido, como ressalta Athos Vellozo, ao examinar o tratamento legal dado ao tribunal do júri nos anos que se seguiram à Proclamação da República:

Por que razão admitir, contrariamente a toda norma jurídica que rege os vários setores do aparelho repressivo penal, um corpo de julgadores leigos, intangíveis em seus desmandos? [...]

Mesmo os juízes togados, quando se lhes confere o poder de livre apreciação das provas, para formarem a sua íntima convicção, é exigido que fundamentem suas decisões - além de se lhes exigir determinadas qualidades e requisitos para o exercício das respectivas funções - assegurando maior garantia à justiça penal, na necessária repressão aos que delinquirem, a fim de não serem meros instrumentos ao sabor das paixões, ódios ou simpatias

E, não obstante essas exigências, a despeito das normas impostas à responsabilidade dos que funcionam no processo criminal, entrega-se o seu julgamento - precisamente nos crimes mais graves - a um tribunal composto de leigos, de irresponsáveis, de incapazes para a função, que irá julgar de consciência, libertos a quaisquer regras, e cujos juízes, dando à consciência a elasticidade que mais lhes convém, proferem decisões as mais disparatadas, as mais injustas e absurdas, contrariando toda a lógica e, até, ao bom senso, sem apoio nos autos, nos debates orais ou em alguma coisa, a não ser, dirão eles, na consciência! (VELLOZO, 1952, p. 34).

De fato, o tribunal do júri era tema de intensos debates tanto na esfera jurídica quanto na esfera pública. Não é de estranhar, portanto, que tenha sido alvo do interesse de Machado de Assis e que, além de ser o objeto central do conto Suje-se gordo!, o tema esteja presente também na série de crônicas por ele publicadas na Gazeta de Notícias, entre 1892 e 1897, sob o título $A$ Semana, ${ }^{\mathbf{3 8}}$ em que encontramos irônicas considerações sobre o júri.

38 A série é composta por 246 crônicas, e em 18 delas o tema do tribunal do júri se faz presente. Particularmente interessante, em sua totalidade, são as que datam de 5 de abril de 1896, de 12 de abril de 1896 e de 9 de agosto de 1896. Para facilitar sua localização, ao citar as crônicas, optamos por indicar a data de sua publicação na Gazeta de Notícias, e não a paginação. 
Em uma das crônicas, Machado discorre sarcasticamente sobre o não comparecimento dos jurados às sessões e sugere que tal prática se deve à falta de apreço pela nobre e liberal instituição do júri:

Esta semana devia ser escrita com letras de ouro. Após três meses de espera, de sorteio, de convites, de multas, de paciência e de citações, constituiu-se o júri! É a segunda vez este ano. Talvez seja a penúltima vez deste século. [...] a nobre instituição do júri, instituição liberal, o julgamento dos pares, etc., não parecia estar no gosto do nosso povo carioca. Este povo era intimado e multado, e nem por isso deixava os seus negócios para ir ser juiz. (ASSIS, 1944, 7 de outubro de 1894).

Há uma outra crônica, em que ele aborda o desinteresse dos jurados pelo exame das provas. Nela, Machado alude ao comentário que ouvira, de que muito frequentemente, ao serem perguntados pelo juiz se precisavam ouvir as testemunhas, os jurados as dispensavam e sugere que outros dos procedimentos também possam ser eliminados:

Também eu ouvi igual dispensa, mas relativamente ao interrogatório do próprio réu. Foi há muitos anos. Interrogado sobre o delito, pediu ele para não falar de assuntos que lhe eram penosos, e os jurados concordaram em não ouvi-lo. Realmente, o acusado merecia piedade, era um caso de honra; mas dispensada a audiência do réu e das testemunhas, não tarda que se faça o mesmo ao promotor e ao defensor, e finalmente à leitura do processo, aliás penosíssima de ouvir, mormente se o escrivão apenas sabe escrever. (ASSIS, 1944, 5 de abril de 1896).

Em outra crônica, o autor reflete especificamente sobre o excesso de escrúpulos dos jurados e sobre seus efeitos no julgamento pautado pela própria consciência:

Demais, os processos são longos, não contando que a admirável instituição do júri - é a melhor escola evangélica destes arredores: "Quem estiver inocente, que lhe atire a primeira pedra!" [...] E o réu, seja de ferimento ou simples estelionato, é restituído ao ofício de roda da criação. O melhor é não punir nada. A consciência é o mais cru dos chicotes. (ASSIS, 1944, 2 de dezembro de 1894).

Nota-se que, nos trechos citados das crônicas - até mesmo pelas características próprias desse gênero -, as críticas ao tribunal do júri são formuladas de modo mais direto e que a ironia é mais explícita; já no conto Suje-se gordo!, temos uma série de elementos figurativos que, remetendo a conteúdos temáticos, são colocados à disposição do leitor e o induzem a questionar a eficácia de tal instituto na concretização da justiça, e a ironia resulta de sofisticada composição que, todavia, ainda está por merecer nossa atenção, a fim de que se alcance 
o sentido intrínseco ao texto.

Para isso, deve-se ter presente o fato de que, no conto, há uma história dentro da história, mediante o emprego da técnica narrativa denominada moldura ou enquadramento ${ }^{39} \mathrm{e}$ do qual resultam, do ponto de vista estrutural, dois níveis narrativos. ${ }^{\mathbf{4 0}}$

Considerando que a capacidade do leitor de perceber a existência desses dois níveis mostra-se essencial para uma melhor compreensão do sentido do texto, cabe explicitar o funcionamento de tal técnica, enquanto estratégia narrativa.

No nível extradiegético, no caso, nível primário que adquire o estatuto de moldura, a situação narrativa se estabelece pelo relato da conversa que ocorrera no intervalo da peça teatral. Já o segundo nível, intradiegético, começa quando o Amigo assume a posição de narrador e passa a relatar duas de suas experiências como jurado. Tal deslocamento da instância narrativa ocorre no terceiro parágrafo e é marcado: do ponto de vista formal e discursivo, pela supressão do travessão - exclusão que define o início do relato confessional do Amigo -; e, do ponto de vista diegético, pela alusão a eventos que aconteceram em espaço diverso, em

39 A denominação é de Wolfgang Kayser (1967), e o emprego de tal técnica pode ser ilustrado recorrendo, no drama, à peça dentro da peça em Hamlet e, na épica, à articulação dos relatos em Decameron e As mil e uma noites. Já Claude Bremond $(1973 ; 1981)$ identifica as configurações que são empregadas em sequências complexas - encadeamento, encaixe e alternância - e caracteriza encaixe como o engaste de uma ou mais sequências dentro de outra que a engloba. Independentemente da nomenclatura que se adote, o que importa é considerar três aspectos: (1) a subordinação que se estabelece entre os níveis narrativos, no caso do enquadramento; (2) as diferentes funções que as articulações entre os níveis podem desempenhar - explicativa, predicativa, temática, persuasiva, distrativa e de obstrução -; e, principalmente, (3) que a tarefa analítica não se restringe à descrição dos níveis narrativos, devendo ser identificada à articulação funcional existente entre eles, de modo a reconhecer suas relações temáticas.

40 Ao examinar o processo de enunciação narrativa, suas circunstâncias e as entidades que dele participam, Gérard Genette (2007) cria uma tipologia dos níveis de narração: o nível extradiegético, que servirá de base para os eventuais desdobramentos de instâncias narrativas no texto, é o nível da narração primeira e se caracteriza pela presença de um narrador que se dirige a um narratário - ambos entidades fictícias e com existência puramente textual; o nível intradiegético (ou diegético) se constitui pela situação em que uma personagem da narrativa primeira assume a função de narrador dentro da história e produz um relato que tem como receptor outra ou outras personagens; e o nível metadiegético - ou hipodiegético, de acordo com Mieke Bal (1990) -, em que uma personagem do universo instituído pelo narrador intradiegético ocupa, por sua vez, a posição de narrador e funda o quarto nível narrativo.

Em relação ao narrador, Genette $(2007 ; 1983)$ oferece duas tipologias: na primeira delas, o narrador é classificado pelo nível de narração em que se encontra, de tal modo que se tem o narrador extradiegético, intradiegético e meta ou hipodiegético; na segunda tipologia, o narrador se distingue pela relação que mantém com a história narrada: o narrador autodiegético é aquele que ocupa também a posição de protagonista; o homodiegético é, além de narrador, personagem secundária da história; e o heterodiegético é exclusivamente narrador, não participando da história como personagem. 
tempo anterior e envolvendo personagens que não figuram na narrativa apresentada no nível extradiegético. ${ }^{41}$

A existência dos dois níveis narrativos e, consequentemente, dos dois espaços físicos referidos no conto, é a base para a construção da analogia entre o teatro e o tribunal do júri: o júri equivale à encenação teatral; acusação, defesa e jurados são apenas atores que desempenham seus papéis; a sentença - tal qual o desfecho da peça de teatro - já foi escrita; e o destino de cada réu está previamente determinado pela sua condição social.

Em outras palavras, se o tribunal do júri se sustenta na ideia de igualdade de todos perante a lei, o que implica a possibilidade de todos virem ocupar a posição de réu ou de jurados, isso não significa a isonomia de julgamento, pois tal igualdade sucumbe em um sistema político em que prevalece a diferença social e no qual o status social interfere nas decisões judiciais.

Aliás, o jogo entre igualdade-desigualdade se faz presente no conto em diversos elementos que, disseminados ao longo do texto, envolvem a duplicidade: os dois réus; acusação e defesa; condenação e absolvição; o Lopes gordo, jurado, e o Lopes magro, réu; e, sobretudo, o preceito bíblico e a máxima do Lopes, que, ao figurar como título, parece sarcasticamente sugerir qual seria a fórmula do sucesso.

Em suma, o conto denunciaria que o fato de o tribunal do júri ser uma instituição liberal, por si só, não viabiliza que seja assegurada a igualdade de todos perante todos. Ademais, ao ressaltar aspectos que, relativos à dinâmica do tribunal do júri, vinculam-se à suscetibilidade do jurado, ao poder de persuasão da linguagem e ao modo como defesa e acusação exploram a atitude de cada um dos réus durante os julgamentos, delas inferindo - e conforme lhes convêm - as manifestações de inocência ou de culpa, o conto também aponta que os jurados estão expostos às manobras retóricas da acusação e da defesa e que, além disso, por poderem desprezar a natureza e o valor das provas que constam nos autos, na melhor das hipóteses, ao julgarem de acordo com as suas consciências, são constrangidos por escrúpulos de natureza moral e religiosa, o que sem dúvida tende a comprometer a realização da justiça.

$\mathrm{O}$ valor de um texto literário reside tanto na multiplicidade de leituras que ele oferece - e a apresentada aqui é apenas mais uma das inúmeras leituras possíveis - quanto na realidade humana e social que ele evoca e, consequentemente, no seu potencial de atualização.

É por isso que, embora atrelado, pela época de sua produção, ao contexto brasileiro da passagem do século XIX ao século XX - tão distante temporalmente -, o sentido do conto

41 A narrativa primária não será propriamente retomada, já que o narrador inicial não mais se manifesta. Entretanto, o contexto que lhe corresponde - os dois amigos conversando no intervalo da peça teatral é mencionado três vezes. As duas primeiras ocorrem quando o Amigo, interrompendo seu relato, declara: "Contarei depressa; o terceiro ato não tarda" (p. 695); "Não lhe digo [...] por já ser tarde; a orquestra está afinando os instrumentos” (p. 696). Já a terceira menção se localiza na última frase do conto, com a alusão que ele mesmo faz ao término do intervalo: “Acabou a música, vamos para as nossas cadeiras” (p. 698). 
Suje-se gordo! e as questões que ele nos coloca podem ser objeto de reflexão também no que se refere ao tribunal do júri e à realização da justiça no contexto atual.

Assim, o terceiro e último procedimento do modelo de percurso analítico-interpretativo consiste em, transcendendo o contexto histórico da produção do texto - sempre que for o caso de obras cuja produção se inscreva em outro momento histórico e cultural -, relacionar os eventos narrados no conto com a situação atual, a qual adquire relevância no sistema de referência de que o leitor contemporâneo dispõe para a construção do sentido a ser atribuído ao conto, na medida em que esse sistema de referência abarca a experiência de sua própria vida e a sua compreensão de mundo. ${ }^{42}$

Com a Constituição de 1988 (BRASIL, 1988) - em que as garantias e direitos fundamentais adquirem o estatuto de princípios -, o tribunal do júri é alçado à condição de instituição democrática, sendo-lhe assegurados, no art. 5, inciso XXXVIII: “a) a plenitude de defesa; b) o sigilo das votações; c) a soberania dos veredictos; d) a competência para o julgamento dos crimes dolosos contra a vida”.

A questão central que se coloca - mesmo com a Lei n. 11.689, de 9 de junho de 2008 (BRASIL, 2008), que fixa os novos procedimentos a serem adotados no tribunal do júri - é em que medida há, no julgamento por íntima convicção, a violação aos preceitos constitucionais e ao processo penal que garantem a liberdade, a ampla defesa e a fundamentação da decisão.

De fato, no tribunal do júri, a liberdade do réu se subordina ao convencimento dos jurados, que - desatrelados de parâmetros técnico-jurídicos e completamente livres para a valoração ou não das $\operatorname{provas}^{\mathbf{4 3}}$ - são mais suscetíveis a toda sorte de manipulação e aos efeitos de artifícios argumentativos, nos quais costumam abundar apelos de cunho social, moral, religioso e emocional. ${ }^{44}$ É favorecida, assim, a arbitrariedade, e sucumbe a garantia

42 Adotamos, aqui, o constructo teórico elaborado por D. del Pino (1998), que ao postular a correspondência, no campo dos estudos semióticos, entre a concepção de sistema de referência e a noção de horizonte, ressalta que o horizonte compreende o conhecimento ativo do leitor - integrado ao contexto histórico-cultural em que ele está inscrito e às suas experiências pessoais - e, por ser o pano de fundo sobre o qual ele projeta os elementos presentes no texto literário a fim de confrontá-los com o que conhece, constitui o sistema de referência de que o leitor se utiliza na construção de sentido.

43 Como destaca Fernando da Costa Tourinho Filho (2008, p. 305), "os jurados têm inteira liberdade de julgar, e o fazem de acordo com a sua consciência, sem ficar adstritos à lei e à prova”.

44 Recorrendo a mesma analogia do tribunal do júri com o teatro - oferecida na complexa estrutura do conto de Machado de Assis -, Aramis Nassif (2008, p. 97) afirma que “a interpretação no palco ou no plenário serve para informar, sensibilizar, emocionar e envolver tanto o espectador no teatro como o jurado no tribunal do júri”. No mesmo sentido, Lenio Streck (2001, p. 114), ao refletir sobre o fato de que a "sorte do acusado" é decidida pelo embate travado entre a acusação e a defesa, ressalta que "Os mais diferentes 
de um julgamento baseado no contraditório, na apreciação dos elementos probatórios e na ponderação.

Ademais, tal contexto é favorecido pela dispensa de fundamentação das decisões dos jurados, o que se mostra incompatível com o preceito constitucional estabelecido no art. 93, inc. IX: "todos os julgamentos dos órgãos do Poder Judiciário serão públicos, e fundamentadas todas as decisões, sob pena de nulidade". ${ }^{45}$

Ao lado do julgamento por íntima convicção - na qual concorrem os eventuais escrúpulos dos jurados e, nos tempos atuais, sobretudo os apelos midiáticos ${ }^{\mathbf{4 6}}$-, da não fundamentação da decisão e da evidente teatralidade que se instaura no tribunal do júri, temos, ainda, a falácia da igualdade social, diante de uma realidade em que os jurados pertencem, majoritariamente, à classe média e a maioria dos réus a classes menos privilegiadas, ${ }^{47}$ havendo um longo caminho a ser trilhado até que a Defensoria Pública esteja devidamente aparelhada para exercer sua democrática função.

O fato é que, como defende Lenio Streck (2001, p. 173-174),

O modelo de Estado Democrático de Direito, garantista e secularizado, dificilmente poderá continuar a conviver com julgamentos nos quais não haja a devida justificação/ fundamentação. O júri, bem como as demais instituições jurídicas, deve ser examinado no contexto de uma sociedade em crise.

tipos de discursos e recursos retóricos são utilizados no plenário. Estilos gongóricos, teatrais, técnicos... Alguns julgamentos tornam-se burlescos”.

45 Nesse sentido, não se pode perder de vista que "só a fundamentação permite avaliar se a racionalidade da decisão predominou sobre o poder, e, principalmente se foram observadas as regras do devido processo penal. Trata-se de uma garantia fundamental e cuja eficácia e observância legitima o poder contido no ato decisório” (LOPES JUNIOR, 2009, p. 195).

46 O alerta é de Aury Lopes Junior (2009, p. 309) que, ao analisar a propensão dos jurados à condenação, menciona o fato de que "os leigos estão muito mais suscetíveis a pressões e influências políticas, econômicas e, principalmente, midiática, na medida em que carecem das garantias orgânicas da magistratura”.

47 A esse respeito, ver Paulo Rangel (2007, p. 480), para quem, "no Júri, os iguais não julgam os iguais, basta verificar a formação do Conselho de Sentença: em regra, funcionários públicos e profissionais liberais. E os réus? Pobres"; e Lenio Streck (2001, p. 118-119), quando alude à composição do corpo de jurados, "que, historicamente, é constituído pelas camadas médio-superiores (portanto, dominantes) da sociedade. Assim, levando-se em conta a circunstância de os acusados, em sua ampla maioria, serem provenientes das camadas pobres da sociedade, pode-se concluir que, quando levados a julgamento frente a um corpo de jurados formado basicamente pelas camadas médio-superiores da sociedade, estarão (os acusados) em face de uma verdadeira luta de classes, que, porém, não será explicitada no plenário do julgamento, eis que, simbólica e ritualisticamente, será amalgamada pelos discursos dos atores jurídicos, que tratarão de esconder a inexorável relação conflituosa existente entre réus e julgadores!" 
Evidencia-se, assim, a atualidade do conto Suje-se gordo!, de Machado de Assis, que conduz o leitor de hoje a questionar-se se os atuais dispositivos legais garantem que o tribunal do júri - agora concebido como instituição democrática - promove a efetiva realização da justiça.

Com isso, concretiza-se a função social da literatura que, segundo Hans Robert Jauss (1993, p. 105), "só manifesta genuinamente as suas possibilidades quando a experiência literária do leitor intervém no horizonte de expectativa da sua vida quotidiana, orienta ou modifica a sua visão do mundo”.

\section{CONSIDERAÇÕES FINAIS}

Sempre que se descortina um novo campo de estudo, muitas são as questões epistemológicas e teóricas a serem enfrentadas, questões que se potencializam quando se trata de campo interdisciplinar, para o qual concorrem aparatos conceituais, pressupostos, metodologias e instrumentos oriundos de áreas que são distintas.

Nossa intenção aqui foi privilegiar os estudos dedicados ao direito na literatura, tendo em vista ser essa a abordagem por meio da qual, normalmente, os pesquisadores - não só do Brasil - iniciam suas incursões no campo do Direito e Literatura. Algumas obras literárias favorecem a aproximação, pois se concentram na representação do mundo jurídico e de seus atores, mas isso não significa que não exijam certo grau de perícia no tratamento com o texto e de sofisticação nas construções de sentido que a partir dele são formuladas, sob pena de a obra perder seu estatuto de objeto estético e ser reduzida a mero instrumento a serviço das ideias que o pesquisador busca defender ou, por meio dela, comprovar.

Assim, foram destacados alguns pressupostos da teoria literária e oferecido um modelo de percurso analítico-interpretativo que pode ser adotado nos estudos sobre direito na literatura, procurando evidenciar que o domínio de subsídios teóricos e metodológicos não só favorece a tarefa do pesquisador como enriquece os resultados da pesquisa.

Por fim, cabe ressaltar que, se a literatura pode promover a ampliação do horizonte de compreensão dos estudantes e profissionais da área jurídica, instigando a reflexão acerca dos fenômenos jurídicos e sociais e colaborando para uma formação mais crítica e humana, o direito também pode fornecer aos estudantes e profissionais da área de literatura subsídios oriundos da esfera jurídica a serem considerados na interpretação do texto literário e integrados na construção do sentido a ele atribuído - aliás, como o demonstra o presente artigo. 


\section{REFERÊNCIAS}

ARAÚJO, José Osterno Campos de. Direito penal na literatura: Shakespeare, Machado e outros virtuoses. Porto Alegre: Núria Fabris, 2012.

ARNOLD, Sonja; KORFMANN, Michael (Org.). Direito e literatura na virada do milênio / Law and literature at the turn of the millennium. Porto Alegre: Dublinense, 2014.

ASSIS, Machado de. Suje-se gordo! In: ASSIS, Machado de. Obras completas. Rio de Janeiro: Nova Aguilar, 1997. p. 694-698.

. A semana. Rio de Janeiro: Jackson, 1944.

BAKHTIN, Mikhail. Questões de literatura e de estética: a teoria do romance. Trad. de Aurora Fornoni Bernardini et al. São Paulo: Editora Unesp; Hucitec, 1988.

BAL, Mieke. Teoría de la narrativa: una introducción a la narratología. Trad. de Javier Franco. Madrid: Cátedra, 1990.

BARTHES, Roland. O efeito de real. In: O rumor da língua. Trad. de Mário Laranjeira. São Paulo: Martins Fontes, 1984.

BOTERO, Andres; MEDINA, Lízia (Org.). Direito e Literatura: estudos jurídicos baseados em obras literárias da segunda metade do século XIX. Curitiba: Juruá, 2013.

BRASIL. Decreto de 18 de julho de 1822. Disponível em: <http://www.planalto.gov.br/ccivil_03/ decreto/Historicos/DIM/DIM-18-7-1822.htm>. Acesso em: 20 mar. 2016.

Constituição Política do Império, de 25 de março de 1824. Disponível em: <http://www. planalto.gov.br/ccivil_03/Constituicao/Constituicao24.htm>.Acesso em: 20 abr. 2016.

. Lei de 20 de setembro de 1830a. Disponível em: <http://www2.camara.leg.br/legin/fed/ lei_sn/1824-1899/lei-37987-20-setembro-1830-565654-publicacaooriginal-89402-pl.html>. Acesso em: 20 abr. 2016.

Código Criminal do Império, de 16 de dezembro de 1830b. Disponível em: <http://www. planalto.gov.br/ccivil_03/leis/LIM/LIM-16-12-1830.htm\#art14>.Acesso em: 20 abr. 2016.

. Código de Processo Criminal de Primeira Instância, de 29 de novembro de 1832. Disponível em: 
<http://www.planalto.gov.br/ccivil_03/leis/LIM/LIM-29-11-1832.htm>.Acesso em: 20 abr. 2016.

. Lei n. 261, de 3 de dezembro de 1841. Disponível em: < http:/ /www.planalto.gov.br/ccivil_03/ leis/LIM/LIM261.htm>. Acesso em: 20 abr. 2016.

Decreto n. 847, de 11 de outubro de 1890a. Disponível em: <http://www.planalto.gov.br/ ccivil_03/decreto/1851-1899/D847.htm>.Acesso em: 20 abr. 2016.

Decreto n. 848, de 11 de outubro de 1890b. Disponível em: <http://www.planalto.gov.br / ccivil_03/decreto/1851-1899/d848.htm>.Acesso em: 20 abr. 2016.

. Decreto n. 1030, de 14 de novembro de 1890c. Disponível em: <http: / www.planalto.gov.br / ccivil_03/decreto/1851-1899/D1030.htm>. Acesso em: 20 abr. 2016.

. Constituição (1891). Disponível em: <http:/ /www.planalto.gov.br/ccivil_03/Constituicao/ Constituicao91.htm>.Acesso em: 20 abr. 2016.

. Lei Federal n. 221, de 20 de novembro de 1894. Disponível em: <http://www.planalto. gov.br/Ccivil_03/LEIS/1851-1900/L0221.htm>. Acesso em: 20 abr. 2016.

Decreto Federal n. 3.084, de 5 de novembro de 1898a. Disponível em: <http://legis. senado.gov.br/legislacao/DetalhaSigen. action?id=399352>. Acesso em: 20 abr. 2016.

. Lei Federal n. 515, de 3 de novembro de 1898b. Disponível em: <http: / /www.camara.gov.br / legin/fed/lei/1824-1899/lei-515-3-novembro-1898-540059-publicacaooriginal-39841-pl.html>. Acesso em: 20 abr. 2016.

. Constituição (1946). Disponível em: <http://www.planalto.gov.br/ccivil_03/Constituicao/ Constituicao46.htm>.Acesso em: 20 abr. 2016.

. Constituição (1988). Disponível em: <http://www.planalto.gov.br/ccivil_03/Constituicao/ Constituicao.htm>. Acesso em: 20 abr. 2016.

Lei n. 11.689, de 9 de junho de 2008. Disponível em: <http://www.planalto.gov.br/ ccivil_03/_Ato2007-2010/2008/Lei/l11689.htm>.Acesso em: 20 abr. 2016.

BREMOND, Claude. La logique des possibles narratifs. L'analyse structurale des récits. Paris: Seuil, avril 1981. (Communications, 8, p. 60-76). 
BREMOND, Claude. Logique du récit. Paris: Seuil, 1973.

CALVO GONZÁLEZ, José. Derecho y narración: materiales para una teoría y crítica narrativista del derecho. Barcelona: Ariel, 1996.

. Direito curvo. Porto Alegre: Livraria do Advogado, 2013.

- Octroi de sens: exercises d'intreprétation juridique-narratif. Quebéc: Les Presses de l’Université Laval, 2008.

CANDIDO, Antonio. O direito à literatura. In: . Vários escritos. Rio de Janeiro: Ouro sobre Azul, 2011. p. 171-193.

CARDOZO, Benjamin N. Law and Literature. Yale Review, v. 14, p. 699-718, 1925.

CARVALHO FILHO, Aloisio de. Machado de Assis e o problema penal. Salvador: Livraria Progresso, 1959.

CHKLOVSKI, Viktor. A arte como procedimento. In: EIKHENBAUM, B. et al. Teoria da literatura: formalistas russos. Porto Alegre: Globo, 1971.p. 105-118.

COSTA, Judith Martins (Org.). Narração e normatividade: ensaios de direito e literatura. Rio de Janeiro: GZ Editora, 2012.

COVER, Robert. The Supreme Court, 1982 term. foreword: "Nomos and narrative". Harvard Law Review, v. 97, n. 1, p. 4-68, nov. 1983.

D’AMATO, A. La letteratura e la vita del diritto. Milano: Ubezzi \& Dones, 1936.

DWORKIN, Ronald. Uma questão de princípio (1985). São Paulo: Martins Fontes, 2001.

ECO, Umberto. I limiti dell'interpretazione. Milano: Bompiani, 1990.

. Opera aperta: forma e indeterminazione nelle poetiche contemporanee. Milano: Bompiani, 1962.

FAORO, Raymundo. Os donos do poder: formação do patronato político brasileiro. 3. ed. São Paulo: Globo, 2001.

FEHR, Hans. Das Recht im Bilde. Bern: A. Francke, 1923. v. 1. 
FEHR, Hans. Das Recht in der Dichtung. Bern: A. Francke, 1931. v. 2.

. Die Dichtung im Recht. Bern:A. Francke, 1936. v. 3.

FLORY, Thomas. El juez de paz y el jurado en el Brasil imperial (1808-1871): control social y estabilidad política del Nuevo Estado. México: Fondo de Cultura Económica, 1986.

FRANCE. Recueil général annoté des lois, décrets, ordonnances, etc. etc. depuis le mois de juin 1789 jusqu'au mois d'août 1830. Paris: Journal des notaires et des avocats, 1835. Disponível em: <http: / gallica. bnf.fr/ark:/12148/bpt6k426353q/f16.image.r=Recueil\%20g\%C3\%A9n\%C3\%A9ral\%20annot\%C3\%A 9\%20des\%20lois\%20,\%20d\%C3\%A9crets,\%20ordonnances>. Acesso em: 20 abr. 2016.

GADAMER, Hans-Georg. Verdad y método I. 10. ed. Salamanca: Sígueme, 2003.

GALUPPO, Marcelo C.; TRINDADE, André Karam; OLIVO, Luiz Carlos Cancellier de (Org.). Direito, arte e literatura. Florianópolis: FUNJAB, 2014.

GAZETA DE NOTÍCIAS. Rio de Janeiro: [s.n.]. 1875-1942. Disponível em: <http://bndigital. bn.br/hemeroteca-digital/>. Acesso em: 20 abr. 2016.

GENETTE, Gérard. Discours du récit. Paris: Seuil, 2007.

. Nouveau discours du récit. Paris: Seuil, 1983.

GHIRARDI, José Garcez. O mundo fora de prumo: transformação social e teoria política em Shakespeare. São Paulo: Almedina, 2011.

GILISSEN, John. Introdução histórica ao direito. Lisboa: Calouste Gulbenkian, 2003.

GODOY, Arnaldo Sampaio de Morais. Direito e literatura: anatomia de um desencanto - desilusão jurídica em Monteiro Lobato. Curitiba: Juruá, 2002.

. Direito, literatura e cinema: inventário de possibilidades. São Paulo: Quartier Latin, 2011.

HUSSERL, Edmund. Meditações cartesianas: introdução à fenomenologia. Trad. de Maria Gorete Lopes e Sousa. Porto: Rés, [s. d.].

INGARDEN, Roman. A obra de arte literária. Lisboa: Calouste Gulbenkian, 1965. 
ISER, Wolfgang. El proceso de lectura. Una perspectiva fenomenológica. In:WARNING, Rainer (Coord.). Estética de la recepción. Trad. de Ricardo Sánchez Ortiz de Urbina. Madri:Visor, 1989. p. 149-164.

O que é antropologia literária? In: ROCHA, João Cezar de Castro (Org.). Teoria da ficção: indagações à obra de Wolfgang Iser. Rio de Janeiro: UERJ, 1999.

JAUSS, Hans Robert. A literatura como provocação: história da literatura como provocação literária. Trad. de Teresa Cruz. Lisboa:Veja, 1993.

JUNQUEIRA, Eliane Botelho. Literatura e direito: uma outra leitura do mundo das leis. Rio de Janeiro: Letra Capital, 1998.

KARAM, Henriete. Espaço-tempo e memória: a subjetividade em “Le temps retrouvé”, de M. Proust. 2008. 607 f. Tese (Doutorado em Letras) - Instituto de Letras, Universidade Federal do Rio Grande do Sul, Porto Alegre, 2008.

KAYSER, Wolfgang. Análise e interpretação da obra literária: introdução à ciência da literatura. Coimbra: Arménio Amado, 1967. 2v.

KLEIN, Julie Thompson. Humanities, culture, and interdisciplinarity: The changing American Academy. Albany: State University of New York Press, 2005.

Une taxinomie de l'interdisciplinarité. Nouvelles perspectives en sciences sociales, v. 7, n. 1, p. 15 48, 2011. Disponível em: <https://www.erudit.org/fr/revues/npss/2011-v7-n1-npss1827471/ 1007080ar.pdf>.Acesso em: 18 fev. 2016.

LOESCH, Frank. Is acquaintance with legal novels essential to a lawyer? Illinois Law Review, Champaign, n. 21, p. 109-146, abr. 1926.

LOPES JUNIOR, Aury. Direito processual penal e sua conformidade constitucional. Rio de Janeiro: Lumen Juris, $2009.2 \mathrm{v}$.

MALAURIE, Philippe. Droit et littérature: une anthologie, Paris: Cujas, 1997.

MARÍ, Enríque. Teoría de las ficciones. Buenos Aires: Eudeba, 2002.

MITTICA, M. Paola. O que acontece além do oceano? Direito e literatura na Europa. Anamorphosis Revista Internacional de Direito e Literatura, n. 1, v. 1, p. 3-36, jan.-jul. 2015. 
MORAES, Renata Figueiredo. As relíquias literárias de Machado de Assis. Tempo e argumento, v. 2, n. 2, p. 182-199, jul./dez. 2010.

NASSIF, Aramis. Júri: instrumento da soberania popular. Porto Alegre: Livraria do Advogado, 2008.

NOGUEIRA, Bernardo Gomes Barbosa; SILVA, Ramon Mapa da (Org.). Direito e literatura: por que devemos escrever narrativas? Belo Horizonte: Arraes, 2013.

NUSSBAUM, Martha C. El conocimiento del amor: ensayos sobre filosofía y literatura. Madrid: A. Machado Libros, 2005.

. L'art d'être juste:l'imagination littéraire et la vie publique. Paris: Flammarion Climats, 2015.

OLIVEIRA, Jane Souto de. "Brasil mostra a tua cara": imagens da população brasileira nos censos demográficos de 1872 a 2000. Rio de Janeiro: Ministério do Planejamento, Orçamento e Gestão; Instituto Brasileiro de Geografia e Estatística (IBGE), 2012.

OLIVO, Luis Carlos Cancellier de. O estudo do direito através da literatura. Tubarão: Editorial Studium, 2005.

OST, François. Raconter la loi: aux sources de l’imaginaire juridique. Paris: Odile Jacob, 2004.

OST, François et al. (Ed.). Lettres et lois: le droit au miroir de la littérature. Bruxelles: Publications des Facultés Universitaires Saint-Louis, 2001.

PERGOLESI, F. Il diritto nella letteratura. Archivio Giuridico "Filippo Serafini”, v. XCVII, fasc. 1, p. 61 104, 1927.

PINO, Dino del. Espaço e textualidade: quatro estudos quase-semióticos. Porto Alegre; São Leopoldo: Mercado Aberto; Unisinos, 1998.

. Introdução ao estudo da literatura. Porto Alegre: Movimento, 1972.

POSNER, Richard. Law and literature. Cambridge: Harvard University Press, 1998.

RADBRUCH, Gustav. Psicologia del sentimento giuridico del popolo. Rivista Internazionale di Filosofia del Diritto, Roma, ano XVIII, n. 3, p. 241-251, maio-jun. 1938.

RANGEL, Paulo. Direito processual penal. 12. ed. rev., ampl. e atual. Rio de Janeiro: Lumen Juris, 2007. 
SANSONE, Arianna. Diritto e letteratura. Milano: Giuffrè, 2001.

SCHÖNGEN, Clarice Beatriz da Costa; PANDOLFO, Alexandre Costi (Org.). Encontros entre direito e literatura: ética, estética e política. Porto Alegre: EDIPUCRS, 2010.

SILVA, Raphael Correia da. Conferência sobre o jury. Revista da Faculdade de Direito de São Paulo, v. 13, 1905, p. 7-32. Disponível em: <http://www.revistas.usp.br/rfdsp/article/viewFile/65045/67656>. Acesso em: 20 abr. 2016.

SIMONIN, Anne. Éloge de l'éclectisme. Penser le champ «Droit et Littérature» à partir des listes de «Legal Novels» (1900-1987). Textyles - Revue des Lettres Belges de Langue Française, n. 31, p. 12-27, 2007.

SINACEUR, M. A. Qu' est ce que l'interdisciplinarité? Revue Internationale des Sciences Sociales, v. 29, n. 4, p. 617-626, 1977. Disponível em: <http://unesdoc.unesco.org/images/0013/001368/136863fo.pdf>. Acesso em: 25 mar. 2016.

SOUSA, José Galante de. Bibliografia de Machado de Assis. Rio de Janeiro: MEC; INL, 1955.

STRECK, Lenio. Tribunal do júri: símbolos \& rituais. 4. ed. Porto Alegre: Livraria do Advogado, 2001.

STRECK, Lenio Luiz; TRINDADE, André Karam (Org.). Direito e literatura: da realidade da ficção à ficção da realidade. São Paulo: Atlas, 2013.

TALAVERA, Pedro. Derecho y literatura. Granada: Comares, 2006.

TOURINHO FILHO, Fernando da Costa. Prática de processo penal. 29. ed. rev. e atual. São Paulo: Saraiva, 2008.

TRINDADE, André Karam; GUBERT, Roberta Magalhães. Direito e literatura: aproximações e perspectivas para se repensar o direito. In: TRINDADE, André Karam; GUBERT, Roberta Magalhães; NETO, Alfredo Copetti (Orgs.). Direito \& literatura: reflexões teóricas. Porto Alegre: Livraria do Advogado, 2008. p. 11-66.

TRINDADE, André Karam; GUBERT, Roberta Magalhães; NETO, Alfredo Copetti (Orgs.). Direito \& literatura: discurso, imaginário e normatividade. Porto Alegre: Núria Fabris, 2010.

TRINDADE, André Karam; STRECK, Lenio (Orgs.). Os modelos de juiz: ensaios de direito e literatura. São Paulo: Atlas, 2015. 
TYNIANOV, Iuri. Da evolução literária. In: EIKHENBAUM, B. et al. Teoria da literatura: formalistas russos. Porto Alegre: Globo, 1971. p. 105-118.

UNITED STATES OF AMERICA. Constitution of the United States of America: analysis, and interpretation. Washington: U.S. Government Printing Office, 2017. Disponível em: <https://www.congress.gov/ constitution-annotated/>. Acesso em: 10 out. 2017.

VELLOZO, Athos Moraes de Castro. Limitações à soberania do júri. Curitiba: Requião, 1952.

WARAT, Luiz Alberto. A ciência jurídica e seus dois maridos. Santa Cruz do Sul: Faculdades Integradas de Santa Cruz do Sul, 1985.

WEISBERG, Richard H. The failure of the word: the protagonist as lawyer in modern fiction. New Haven: Yale University Press, 1984.

. Wigmore's legal novels revisited: new resources for the expansive lawyer. Northwestern Law Review, v. 71, n. 1, p. 17-28, 1976.

WEISBERG, Richard H.; KRETSCHMAN, Karen L. Wigmore's legal novels expanded: a collaborative effort. Maryland Legal Forum, v. 7, n. 2, p. 94-103, 1977.

WELLEK, René;WARREN, Austin Warren. Teoria da literatura. Lisboa: Europa-América, 1976.

WHEELWRIGHT, Philip. The burning fountain. Bloomington: University Indiana Press, 1968.

WHITE, James B. Law as Language: reading law and reading literature. Texas Law Review, v. 60, p. 415 445, 1982.

. Law as rhetoric, rhetoric as law: the arts of cultural and communal life. University of Chicago Law Review, v. 52, n. 3, p. 684-702, verão 1985.

The legal imagination: studies in the nature of legal thought and expression. Boston; Toronto: Little; Brown, 1973.

WIGMORE, John H. A list of legal novels. Illinois Law Review. The Brief, v. 2, p. 124-127, jan. 1900.

. A list of legal novels. Illinois Law Review, v. 2, n. 9, p. 574-593, abr. 1908.

. A list of one hundred legal novels. Illinois Law Review, v. 17, n. 1, p. 26-41, maio 1922. 
QUESTÕES TEÓRICAS E METODOLÓGICAS DO DIREITO NA LITERATURA: UM PERCURSO ANALÍTICO-INTERPRETATIVO : $86 \mathbf{5}$

\section{Henriete Karam}

DOUTORA EM Estudos LiteráRIOS PELA UniVERSIDADE FEDERAL do Rio Grande do Sul (UFRgS). Mestre em TEORIa Literária pela Pontifícia Universidade Católica do Rio Grande do Sul

(PUCRS). Professora do Programa de Pós-Graduação em Direito da Faculdade Guanambi (FG). Professora

Colaboradora do Programa de Pós-Graduação em Letras dA UFRGS. Professora Convidada da Especialização EM Psicanálise da UniVERsidade do VALE do RIO dOS SinOS (UNisinOS). Pesquisadora do SerTão - Núcleo Baiano de

Direito e Literatura (CESG/CNPQ). Membro-Fundadora da

Rede Brasileira Direito e Literatura (RDL). Editora na ANAMORPHOSIS - REVISTA INTERNACIONAL DE DIREITO E LITERATURA.

henrietelardl.org.br 